\title{
THE WINTER CAMP OF THE VIKING GREAT ARMY, AD 872-3, TORKSEY, LINCOLNSHIRE
}

\author{
Dawn M Hadley, FSA, and Julian D Richards, FSA, \\ with contributions by Hannah Brown, Elizabeth Craig-Atkins, \\ Diana Mahoney-Swales, Gareth Perry, Samantha Stein and Andrew Woods
}

Dawn M Hadley, Department of Archaeology, University of Sheffield, Northgate House, West Street, Sheffield Si 4ET, UK. Email: d.m.hadley@sheffield.ac.uk

Julian D Richards, Department of Archaeology, University of York, The King's Manor, York YOI 7EP, UK. Email: julian.richards@york.ac.uk

This paper presents the results of a multidisciplinary project that has revealed the location, extent and character of the winter camp of the Viking Great Army at Torksey, Lincolnshire, of AD 872-3. The camp lay within a naturally defended area of higher ground, partially surrounded by marshes and bordered by the River Trent on its western side. It is considerably larger than the Viking camp of 873-4 previously excavated at Repton, Derbyshire, and lacks the earthwork defences identified there. Several thousand individuals overwintered in the camp, including warriors, craftworkers and merchants. An exceptionally large and rich metalwork assemblage was deposited during the Great Army's overwintering, and metal processing and trading was undertaken. There is no evidence for a pre-existing Anglo-Saxon trading site here; the site appears to have been chosen for its strategic location and its access to resources. In the wake of the overwintering, Torksey developed as an important Anglo-Saxon borough with a major wheel-thrown pottery industry and multiple churches and cemeteries. The Torksey evidence allows for a radical reappraisal of the character of Viking winter camps, and the legacy of the Viking Great Army for Anglo-Saxon England.

\section{BACKGROUND}

From $\mathrm{AD} 865$ to 879 a Viking army wreaked havoc on the Anglo-Saxon kingdoms, leading to political conquest, settlement on a substantial scale and extensive Scandinavian cultural and linguistic influence in eastern and northern England. This critical period for English history was followed by revolutionary changes in land ownership, society and economy, including the growth of towns and industry, while transformations in power politics would ultimately see the rise of Wessex as the pre-eminent kingdom of Anglo-Saxon England. Yet despite the pivotal role of the so-called Great Army (micel here) in these events, little is known of it; documentary sources provide few insights into its activities and intentions, and archaeological evidence has largely remained elusive. The size of the army and the scale of subsequent settlement have been disputed, but the debate about the impact of Scandinavian raiders and settlers is typically informed by evidence that has widely differing levels of chronological resolution and relates to diverse social, economic and political contexts; scholars have long struggled to integrate this evidence effectively. ${ }^{\mathrm{I}}$

I. Hadley 2006, I-27; McLeod 20I4, I-42.

(C) The Antiquaries Journal, 20I6. This is an Open Access article, distributed under the terms of the Creative Commons Attribution licence (http://creativecommons.org/licenses/by/4.0/), which permits unrestricted re-use, distribution, and reproduction in any medium, provided the original work is properly cited. 
This paper provides a fresh perspective on the Viking Great Army and its impact on Anglo-Saxon England, based on new tightly dated and contextualised evidence from Torksey. The Anglo-Saxon Chronicle tells us that in late AD 872 'the army went into Northumbria, and it took up winter quarters at Torksey, in Lindsey; and then the Mercians made peace with the army'. ${ }^{2}$ While it has long been assumed that this occurred in the vicinity of the present-day village of Torksey, on the River Trent $c$ I4 $\mathrm{km}$ north west of Lincoln, only now has the site of the Viking winter camp been precisely located and its extent established. Torksey offers a unique research opportunity as both the camp and the adjacent urban settlement that developed in the wake of the overwintering are unencumbered by later development. Hence from 20 II to 2015 we undertook an archaeological evaluation at Torksey as part of a wider research agenda to examine the impact of ninth-century Viking armies, to illuminate their scale, complexity and intentions, and to provide new insights into the relationship between raiding, political conquest and settlement.

\section{THE VIKING GREAT ARMY}

The Anglo-Saxon Chronicle records that the Great Army landed in East Anglia in $865 .{ }^{3}$ This was evidently larger than any previous Viking force and it became a constant threat, as it stayed in England through the winter. Over the following years it engaged in battle across eastern and northern England, leading each of the Anglo-Saxon kingdoms to 'make peace', as the Chronicle puts it. This is doubtless how the Army acquired many of the resources and allies it needed for a sustained campaign that marked a change in tactics from previous intermittent raids. ${ }^{4}$ Viking armies had overwintered before - on the Isle of Thanet, in the mouth of the Thames, in 850 and on the Isle of Sheppey, in Kent, in 855 - but these were apparently isolated episodes on coastal sites. ${ }^{5}$ The new force appears to have embarked on a phase of political conquest in which it exploited internecine warfare and played a role in appointing new kings from among its newly acquired allies drawn from the local elite. ${ }^{6}$ The decade or so from 865 witnessed the transformation of the Great Army from raiders to settlers, hastening the demise of the separate kingdoms of Mercia, East Anglia and Northumbria. In 876 , one force 'shared out the land of the Northumbrians, and they proceeded to plough and support themselves', and another force settled in Mercia in $877 .{ }^{7}$ The remainder of the Great Army, led by Guthrum, was defeated in 878 by the West Saxons under Alfred at Edington, in Wiltshire. As part of the ensuing peace negotiations, Guthrum and thirty of his warriors were baptised; then, in 880, the Army went to East Anglia 'and settled there and shared out the land'. ${ }^{8}$ Subsequently, Guthrum and Alfred famously engaged in the making of a treaty, dividing out their areas of jurisdiction, and making arrangements for relations between their followers concerning legal disputes, trade and the

2. Manuscripts C, A and B contain the extended version: Her for se here on Norðhymbre, and he nam winter setl on Lindesse cet Tureces iege, and pa namon Mierce frið wið pone here, while manuscript D notes only that 'In this year the army took up winter quarters at Torksey': Whitelock I96I, 47.

3. Ibid, 45 .

4. McLeod 2006, I46-7.

5. Whitelock I96I, 42-3.

6. Ibid, 46-7; Blackburn 2005, 23-5.

7. Whitelock I96I, 48.

8. Ibid, 50; Keynes and Lapidge 1983, 85 . 
movement of people. Coins were minted in Guthrum's realm, on some of which he used his baptismal name of Æthelstan. These initiatives were part of the process by which Guthrum became a king in a western European guise. ${ }^{9}$

Yet despite the importance of this pivotal period in Anglo-Saxon history, the army that precipitated these changes is poorly understood. The size of Viking armies has been much debated, especially following Peter Sawyer's attempts some fifty years ago to challenge previous assumptions about the large scale of the Viking onslaught. Sawyer argued that translating the term here as 'army' was misleading; it was used in the early seventh-century laws of King Ine to mean any group numbering more than thirty-five men: 'If a here could be three dozen men, it would be as well not to call it an "army"'. He maintained that the Chronicle exaggerated the numbers of ships involved in Viking raids, and argued that the difficulty of keeping a large army in the field precluded Viking armies comprising more than a few hundred men. ${ }^{\text {IO }}$

Sawyer also attempted to mobilise archaeological evidence. However, he relied on antiquarian speculation about possible Viking encampments in his argument for the small size of the armies; since the sites concerned were undated, they did not readily support his case without some circularity of argument. For example, in the I920s Sir Cyril Fox had dismissed the notion that the earthwork known as Gannock's Castle was the site of the Viking winter camp of $9 \mathrm{I} 7$ recorded at Tempsford (Bedfordshire), because at $c$ I $20 \times 84 \mathrm{ft}$ $(c 37 \times 26 \mathrm{~m}$ ) it would only have accommodated around $270 \mathrm{men}$. However, Sawyer argued that there was 'no reason to think that the here mentioned by the Chronicle was much larger than this'. In contrast, in I903, Isaac Chalkley Gould had identified an earthwork some 500 yards $(457 \mathrm{~m})$ long as the fortress built by a Viking army in 893 at Shoebury (Essex), and Sawyer explained the larger size by describing it as a place intended to shelter the women, ships and property of the raiders during campaigns and ... the men and horses as well'. ${ }^{\text {II }}$

Nicholas Brooks subsequently demonstrated the flaw in Sawyer's insistence that the Anglo-Saxon Chronicle is an unreliable witness to the numbers of ships that Viking raids comprised. He showed that the Chronicle is, in fact, notably restrained in its assessments of the scale of most of the raids and, moreover, that the estimates of the numbers of ships sometimes 300 or more - are corroborated by Frankish, Irish and Spanish Muslim sources: 'the Chronicle's figures for Viking fleets are neither random nor wild; they avoid the obvious exaggerations of less well-placed or more colourful continental sources, and they mostly fit a consistent pattern of Viking activity that is credible and circumstantial' ${ }^{12}$ Brooks also argued that the Great Army was more successful than contemporary Viking armies raiding on the continent, because it was demonstrably larger than those armies. It was this that led to the 'shattering effect which they achieved' on Anglo-Saxon kingdoms and the Church. ${ }^{\text {I3 }}$ While there was still no reliable archaeological evidence concerning the encampments of Viking armies, Brooks drew attention to the documentary evidence suggesting that the Great Army typically based itself at the royal and administrative centres of the Anglo-Saxon kingdoms, chosen 'precisely because they already had defences', some of them substantial Roman fortifications. ${ }^{14} \mathrm{He}$ concluded that the size of the places the army chose as their

9. Blackburn 2005; Kershaw 2000.

Io. Sawyer 1962, I20, I26.

II. Gould 1903; Sawyer 1962, I27.

I2. Brooks I979, 7 .

13. Ibid, II.

I4. Ibid, 9 . 
winter bases "would be inexplicable unless the "large" Danish armies were numbered in thousands rather than hundreds'. ${ }^{15}$

The places at which the Great Army spent each winter between 865 and the mid-870s, when permanent settlement commenced, are critical to our understanding of the Viking impact, including scale, composition and the range of activities in which the Army was engaged. Yet although the Chronicle records the overwintering sites, this has proven only partially helpful for locating and exploring Viking encampments; in some cases it is unhelpfully vague (eg 'East Anglia' in 865-6), and even where a precise location is named, modern development has rendered the sites archaeologically inaccessible (eg York in 866-7 and 868-9, Nottingham in 867-8, Thetford in 869-70, Reading in 870-I and London in 87I-2). ${ }^{16}$ There are, however, two exceptions: Torksey (872-3) and Repton $(873-4)$.

Excavations and geophysical survey by Martin Biddle and Birthe Kjølbye-Biddle at Repton (I974-93) identified a substantial ditch, some 4m deep, which formed a relatively small D-shaped enclosure, $c 0.4$ ha in size. ${ }^{17}$ This did nothing to challenge the view that Viking armies can only have been numbered in the hundreds. ${ }^{18}$ Four furnished graves were associated with the recorded overwintering, while excavation of a former mausoleum recovered the disarticulated remains of at least 264 individuals, among which 82 per cent of the sexed bones were male and described as 'robust'. Radiocarbon dating suggested that these remains dated to no later than the late ninth century, and the deposit was interpreted as at least partly comprising members of the Great Army. Other than some indication of damage inflicted on the church, investigations at Repton revealed little more of the activities of the Great Army, but this can now be seen as a reflection of the lack of metal detector and landscape survey. ${ }^{\text {I9 }}$ Nonetheless, for a generation Repton has served as the prototype for Viking encampments. ${ }^{20}$ At Torksey our project now offers a different perspective. We have securely identified the precise location of the overwintering of 872-3 through a programme of archaeological evaluation and the plotting of an exceptional concentration of metalwork, including ingots, hack-metal and coinage (fig I). Our work has also revealed that the camp was $c$ 55ha in extent, considerably larger than that identified at Repton, and characterised by a wider range of activities. Important as the excavations at Repton remain, the scale and character of this new evidence from Torksey forces a radical reappraisal of the Viking Great Army.

The new insights from Torksey are timely given recent work on comparable sites in both England and Ireland. Metal-detecting, excavation and landscape survey have revealed the location of another, as yet unpublished, winter camp at Aldwark, north of York. ${ }^{2 \mathrm{I}}$ This is not a documented winter camp, but on the basis of the date of the metalwork, it has been

I5. Ibid, II.

I6. Whitelock I96I, 46-7; it has been suggested that the camp at Reading lies beneath the site of the medieval abbey: Graham-Campbell 2004, 34-5, 38.

I7. Biddle and Kjølbye-Biddle I992, 40, and 200I, 59, give an internal area of I.46ha, but recalculation by Stein 20I5, 43, and Guilbert 2004, 250, 254 n I7, and comparison with Ordnance Survey maps confirms that a figure of 0.4 ha is nearer the mark, suggesting that I.46ha is a misprint for $0.46 \mathrm{ha}$.

I8. Williams $2013, \mathrm{I} 7$.

I9. Biddle and Kjølbye-Biddle 200I, 60-8I.

20. For example, Edgeworth 2008, I3.

2I. Formerly known by the portmanteau name of Ainsbrook (from the surnames of the metal detectorists who identified the site) and more recently as 'a riverine site in north Yorkshire' or 'a riverine site north of York' (ARSNY); Williams 20I5, 99. 


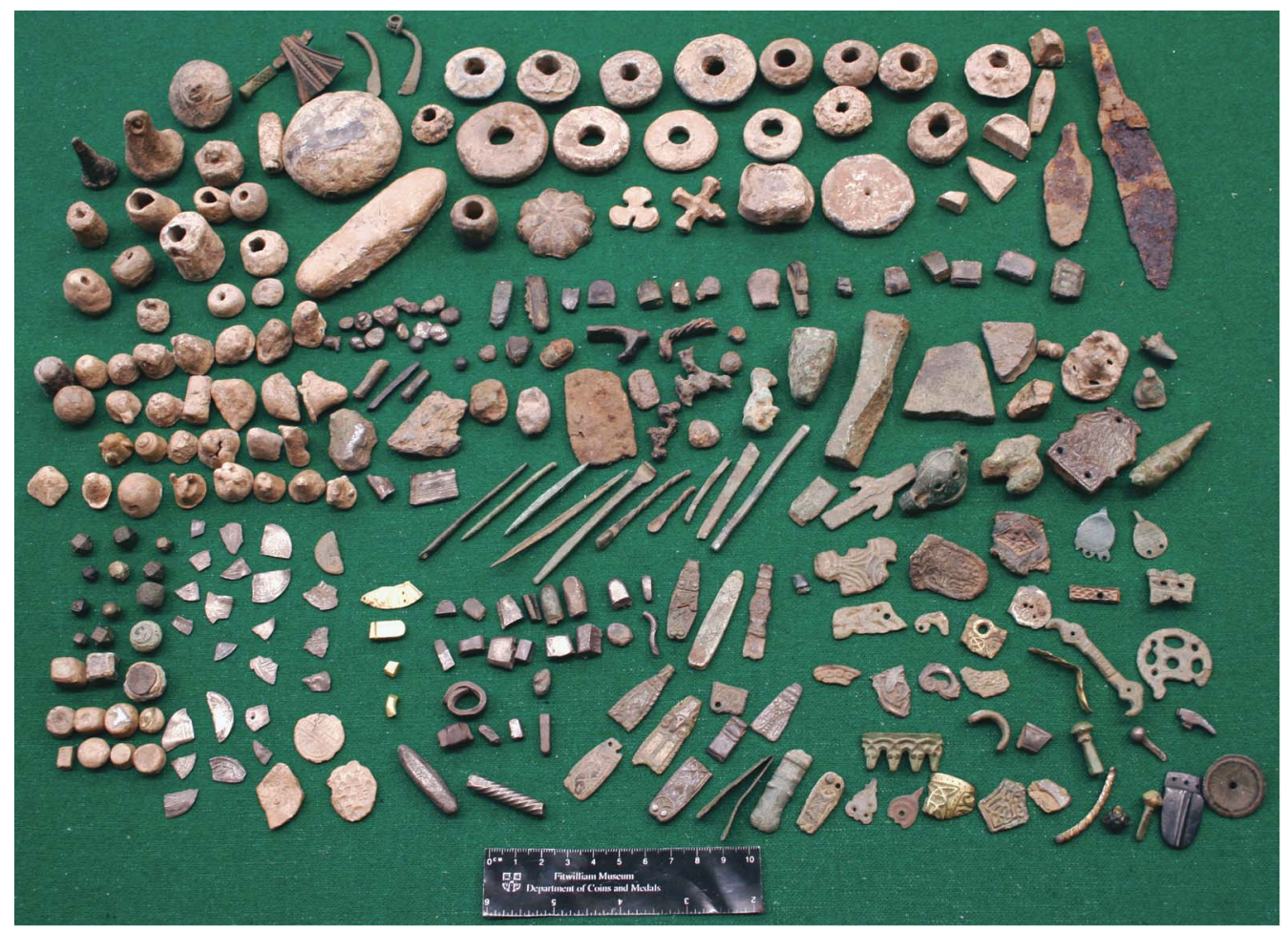

Fig I. A selection of metal-detected finds from the Viking winter camp at Torksey. Photograph: (C) Fitzwilliam Museum, Cambridge

associated with the movement of part of the Great Army back to Northumbria in $874-5 .{ }^{22}$ Evidence for the operation of a bullion economy, metal-working and trade has been recovered. The site extended over an area of $c 3$ Iha, surrounded by a sub-rectangular ditched enclosure, possibly of early medieval date. Limited landscape analysis has revealed that the site was on higher ground above the flood plain of the River Ouse and that windblown deposits may have obscured any archaeological features. ${ }^{23}$

The Annals of Ulster record the locations at which Viking armies in Ireland were based, sometimes describing them as longphuirt (plural for 'ship-place' or 'ship-harbour'), with the earliest recorded being at Lough Neagh (Northern Ireland) in 840 and Dublin in 84I. Whether the longphort should be regarded as a specific monument type has been extensively debated, but recent work has begun to identify their locations through excavation, survey and recognition of a suite of morphological and locational characteristics. ${ }^{24}$ Fieldwork at Annagassan (Co. Louth) has illuminated the longphort constructed at Linn Duachaill in 84I. Geophysical survey and excavation has identified a rampart, comprising a bank and ditch, of $c 245 \mathrm{~m}$ running from the River Glyde to the sea, and cutting off a $1.18 \mathrm{~km}-\mathrm{long}$ section of the peninsula. The geophysical survey also identified areas of burning and 


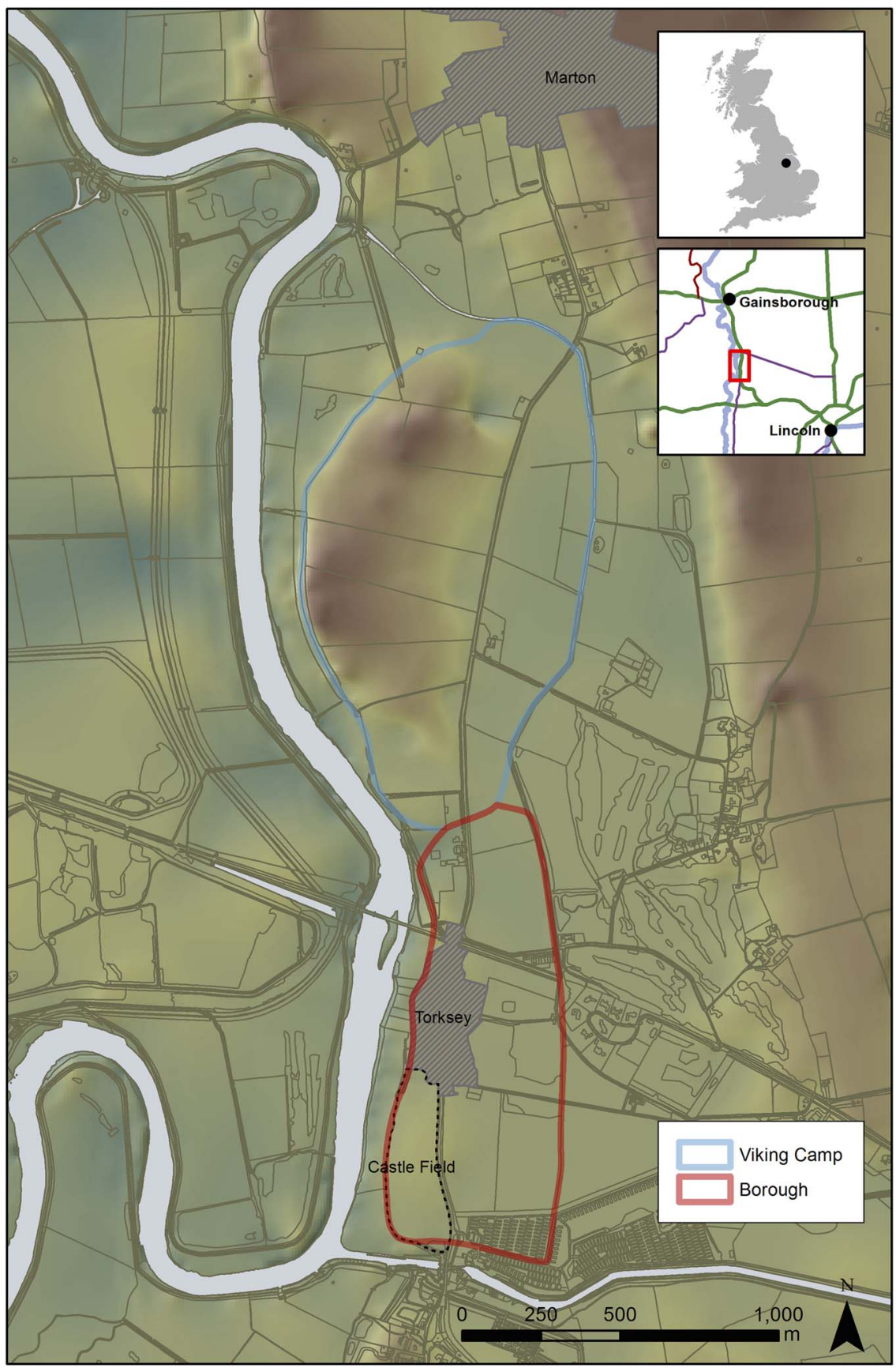

Fig 2. Location plan showing the study area and the approximate outlines of the Viking winter camp and the Anglo-Scandinavian borough. Illustration: base map of this and subsequent figures derived from $2 \mathrm{~m} \mathrm{LiDAR}$ data, Environment Agency (C) 20I4, all rights reserved; field boundaries from Ordnance Survey Mastermap

(C) Crown Copyright/database right 2014, an Ordnance Survey/EDINA supplied service; general map of GB derived from Ordnance Survey MiniScale map 
occupation 'consistent with industrial activity and settlement', and excavation revealed debris from metal-working, ship roves and rivets, hack-silver, a lead weight, a fishing weight, an iron knife and what has been interpreted as a weighing scale beam. ${ }^{25}$ Finally, the recent publication of the excavations at Woodstown (Co. Waterford) has presented evidence for a Viking encampment. It is not specifically recorded as a longphort, although this part of Ireland is poorly represented in surviving documentary sources, and excavation suggests that it was occupied for a longer period of time than other sites discussed in this paper, from the mid-ninth century until the early to mid-tenth century. Two adjacent D-shaped enclosures encompass $c$ 2.9Iha, and evidence for iron-working, silver-working, glass-working, ship repair and trade has been identified. A burial containing weaponry has also been excavated. ${ }^{26}$

\section{AIMS AND METHODS}

Over the last twenty years, several thousand pieces of early medieval metalwork and coins have been recovered by metal detector users from six fields to the north of the modern village of Torksey. ${ }^{27}$ These finds first came to scholarly attention in the I990s, and in his overview of Anglo-Saxon Lincolnshire they were interpreted by Sawyer as evidence for a market or fair of eighth- and ninth-century date, albeit that he accepted that 'some of the ninth-century coins were probably brought by Vikings' ${ }^{28}$ Torksey was described by Katharina Ulmschneider in 2000 as a 'very productive' site. At that time, so-called 'productive' sites, characterised by unusual concentrations of coins and other metalwork of the Middle Anglo-Saxon period, were increasingly being discovered in eastern England by metal-detecting. ${ }^{29}$ However, in a paper published two years later, Mark Blackburn highlighted the concentration of ninthcentury coins, which implied 'a period of exceptional activity at Torksey', and he linked the finds, which then included eleven Arabic dirhams as well as hack-metal, ingots and copperalloy weights, with the Viking overwintering of 872-3, although the precise locations in the parish from which the material was coming were unknown to him..$^{30}$ An updated list of finds was published in 20I 1 , by which time it was apparent that most of the eighth-century coins were not from the site of the winter camp, now identified as 'several ploughed fields adjoining the Trent'. ${ }^{3 \mathrm{I}}$ Blackburn estimated that the finds were coming from an area of $c 26$ ha, but our fieldwork indicates that the size of the camp was, in fact, nearer to 55 ha (fig 2). ${ }^{32}$

In order to set this exceptional metal-detected assemblage in context, we have undertaken a five-year programme of archaeological investigation employing a variety of techniques, including geophysical survey, fieldwalking, environmental analysis and smallscale excavation. By overlaying the various forms of evidence, it is possible to make sense of the different categories of data. Our aims have been to define the location and scale of the camp, its physical nature and organisation, the activities undertaken there and its legacy. We have asked why the Viking army chose the site, and examined its relationship to any

25. Kelly 2015, 82-3.

26. Bill 20I4; Ó Floinn 20I4; Sheehan 20I4; Young 20I4; Hurley 2014.

27. Blackburn 2002; 2011 .

28. Sawyer 1998, 197.

29. Ulmschneider 2000, 67.

30. Blackburn 2002.

31. Blackburn 20II, 225, 245.

32. Ibid, 22I, 245 . 
pre-existing settlement, and we have assessed the role played by this overwintering in the subsequent emergence of the borough of Torksey to the south. ${ }^{33}$ Earlier excavations within the area of the borough, evidently once much larger than the current village of Torksey, had identified at least four cemeteries and fifteen pottery kilns of ninth- to eleventh-century date. ${ }^{34}$ However, the spatial and chronological relationship between the borough and the winter camp was previously unclear. Our project has major implications for the wider understanding of Viking armies, their strategies and composition, and their interaction with local populations as well as the subsequent revolutionary changes in Late Saxon pottery industries and the development of Anglo-Saxon towns.

The project aims have been addressed via eight specific objectives, employing a multidisciplinary team of archaeologists, geomorphologists, numismatists and historians, and by using a range of techniques:

I. Geoarchaeological investigation of the winter camp and its environs, employing auguring, test pitting, optically stimulated luminescence (OSL) dating and pollen analysis, to understand the nature and development of the landscape, and allow us to visualise its likely appearance on the eve of the arrival of the Viking Great Army.

2. Geophysical survey of the winter camp to identify archaeological features associated with the Viking camp and with other phases of activity.

3. Fieldwalking and geo-referenced metal-detector survey within the Viking camp to identify and date activity foci.

4. Trial and test-pit excavations to assess the visibility and depth of buried archaeological features within the winter camp.

5. Concordance and cataloguing of the metal-detected finds known to be from the Viking camp (with a cut-off date of August 2015) to integrate a range of disparate sources.

6. Fieldwalking and geophysical survey of Castle Field, within the Anglo-Saxon borough, to investigate the Torksey pottery industry.

7. Petrological thin-section study of the pottery and its clay sources to help understand the industry and inform broader issues of its relationship to the winter camp and borough.

8. Assessment and radiocarbon dating of the excavated cemeteries in Torksey to understand their relationship to the winter camp and borough.

The focus of this paper is on the winter camp itself (objectives $\mathrm{I}-5$ ), as our study of the Torksey pottery industry is being published separately, ${ }^{35}$ although reference is made to the key outcomes of the other objectives (6-8) where they illuminate the camp and its impact. A searchable and illustrated database of all early medieval finds, and reports covering all objectives, are included in the digital archive, curated by the Archaeology Data Service; together with the current paper, they offer a full and up-to-date catalogue of all the metal-detected finds. ${ }^{36}$ A selection of these finds have been discussed in previous publications, ${ }^{37}$ but our project has collated published sources, current Portable Antiquities

33. Barley 1964, I66-7; Sawyer 1998, I96-7.

34. Barley I964 and I98I; Field I990; Palmer-Brown I995; Williams and Field 2002; Rowlandson 2005; Rowe 2008; Perry 2016; Hadley and Richards 2016b.

35. Perry 2016.

36. Hadley and Richards 2016a. The project's physical archive will be deposited in Lincoln Museum, with accession numbers prefixed TORKI2 and TORKI3.

37. For example, Blackburn 2002 and 201 I; Naismith 2005. 
Scheme (PAS) records and museum accessions along with newly recovered finds. By integrating these strands of information with the results of targeted fieldwork and dating, we are able to demonstrate the value of metal-detected evidence through a contextualised approach on a scale not hitherto seen. ${ }^{38}$

\section{THE LANDSCAPE OF THE VIKING WINTER CAMP}

The winter camp was located east of the River Trent, between the modern villages of Torksey and Marton, and straddling the parishes of Torksey and Brampton (OS grid reference sk 835805). This was a strategically important nodal point in the regional transport network, just south of a crossing point over the river, from which the Roman road now known as Till Bridge Lane ran south east to join Ermine Street just north of Lincoln. ${ }^{39}$ In the medieval period (and probably earlier), Torksey was on a key transport route from the south to York, as travellers transferred from road to river at this point; according to Domesday Book, its inhabitants had the special responsibility of accompanying royal messengers to York 'with their ships and their means of navigation'. ${ }^{\circ}$ The position of Torksey within reach, should the need arise, of Northumbria and the heart of Mercia is striking. The Trent would have provided access to the Midlands and, downstream, to the Humber estuary and thence to York or the North Sea. ${ }^{4 \mathrm{I}}$ This facilitated movement of the army between the kingdoms, but also allowed control over other travellers into and out of Mercia. It is also possible that waterborne access into Lindsey was controlled from Torksey, as it is located adjacent to the Foss Dyke, a canal of probable Roman construction, which connects the Trent to Lincoln. Although we cannot be certain that it was navigable in the ninth century, the transportation of pottery produced at Torksey to Lincoln in the following century suggests that it was open by then. ${ }^{42}$

The current channel of the Trent does not necessarily correspond with its early medieval course. It is likely, however, that climatic deterioration from the fourth to the tenth centuries led to the formation of an unstable, multi-channelled fluvial system with semipermanent wetlands across the wider valley floor, interspersed with areas of raised ground formed by the Mercia Mudstone and sand and gravel islands. Our programme of coring and radiocarbon dating of peat sequences to the east of the winter camp has revealed that there had been a palaeochannel of the Trent up until the Bronze Age, when upstream siltation cut it off from the river, and peat deposits began to form. ${ }^{43}$ Without an active channel, and with water levels averaging $\mathrm{I}-2 \mathrm{~m}$ higher than they are today, the low ground east of the camp would have remained a wetland, allowing peat to accumulate into the early medieval period (fig 3 [2]). Sediment mapping to the north and south of the site revealed not peat but silt (fig 3 [I and 4]), suggesting that these areas remained open to the Trent, which would have provided naturally occurring seasonal tidal ports, with gently sloping

38. Metal-detected evidence has transformed our understanding of Viking Age England (Richards et al 2009), but has hitherto been largely discussed without reference to context (eg Kershaw 2013) or on a smaller scale (eg Richards et al 1999).

39. Whitwell $1992,50$.

40. Sawyer 1998, I8; Foster and Longley I924, II.

4I. Edwards and Hindle 1991, I28, argue that the Trent was navigable as far upstream as Burtonupon-Trent in Staffordshire.

42. Sawyer 1998, 197.

43. Wessex Archaeology 1997; Stein 2013. 


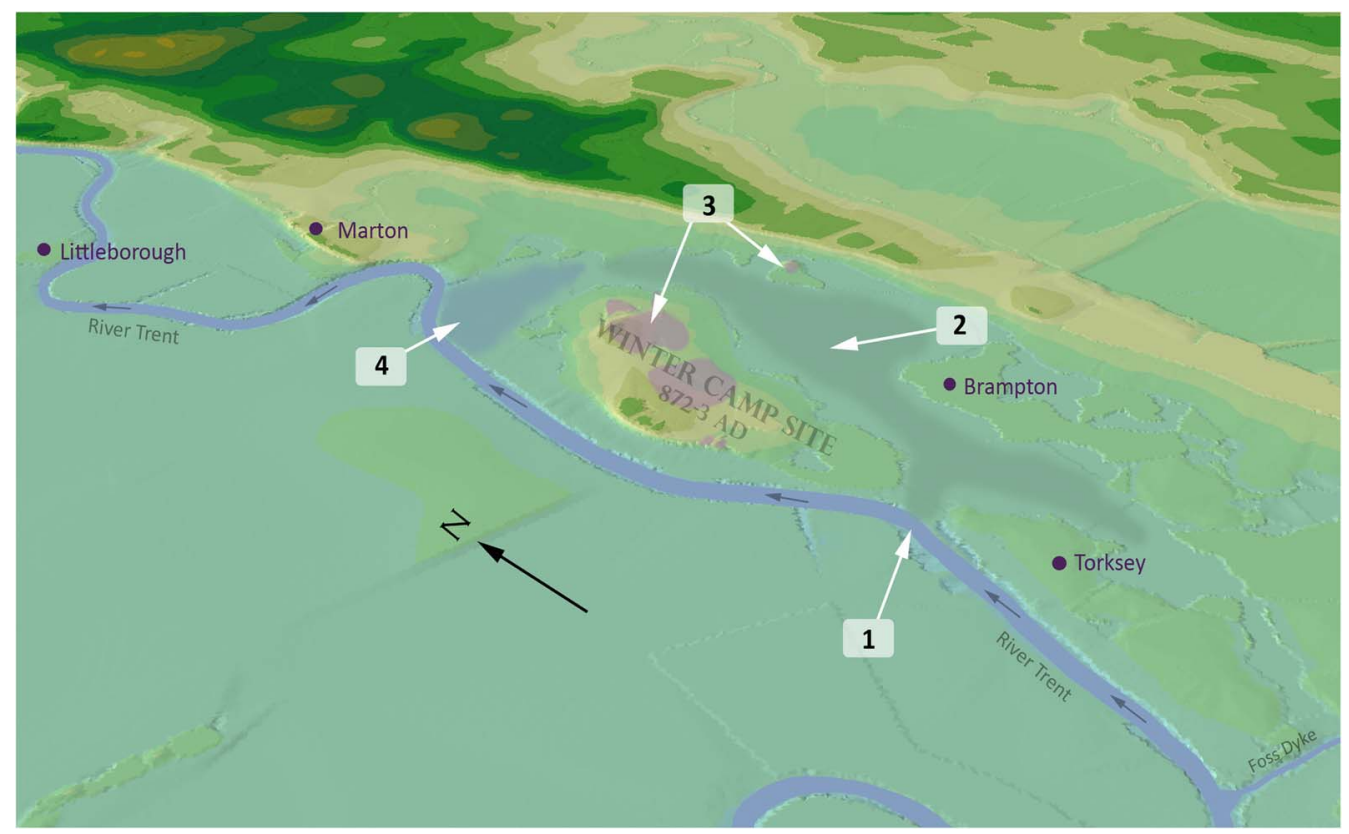

Fig 3. The ninth-century landscape of the winter camp

sandbanks leading up to the higher ground of the winter camp. The area to the north of the site would have flooded regularly with the tidal influx of the Trent, as it continues to do to the present day when the Trent is in flood (fig 3 [4]). Indeed, the place name 'Marton' comes from the Old English mere-tūn, meaning 'pool farm', arguably derived from its position on the Trent flood plain. ${ }^{44}$ Modern land management, including the digging of drainage channels and the installation of a pump-house at Marton in the nineteenth century, has had a significant impact, and geoarchaeological analysis was essential in determining the landscape setting of the winter camp. ${ }^{45}$

In the winter of $872-3$, bounded to the west by the Trent and surrounded by wet and marshy ground, the site of the Viking camp was effectively an island. A prominent bluff, 5-Iom in height, overlooked the floodplain, gradually becoming less pronounced towards its northern end, the land sloping gently down to the east and north east (figs 2, 3 [3] and 4). Although the highest point is only $c$ Iom higher than the modern village, this is a significant difference in the context of the surrounding landscape. The vantage point offered by the elevated location, combined with access to the Trent, must have made it particularly attractive to the Great Army. Viking armies are frequently recorded as occupying islands, including Thanet (Kent) in 850, Sheppey (Kent) in 855, an unnamed island in the River Colne (Hertfordshire) in 893 and an island called Mersea out in the sea off the Essex coast in $894 \cdot{ }^{46}$ On the continent Viking armies are also known to have based themselves on islands in major rivers, and the advantages that this offered are suggested in a late ninth-century account by Adrevaldus, a monk from Fleury Abbey (France), of a Viking army on an island in the Loire where they 'held crowds of prisoners in

44. Cole 1992; Coates 2008, 84.

45. Stein 20II; 2012.

46. Whitelock I96I, 42-3, 55-6. 


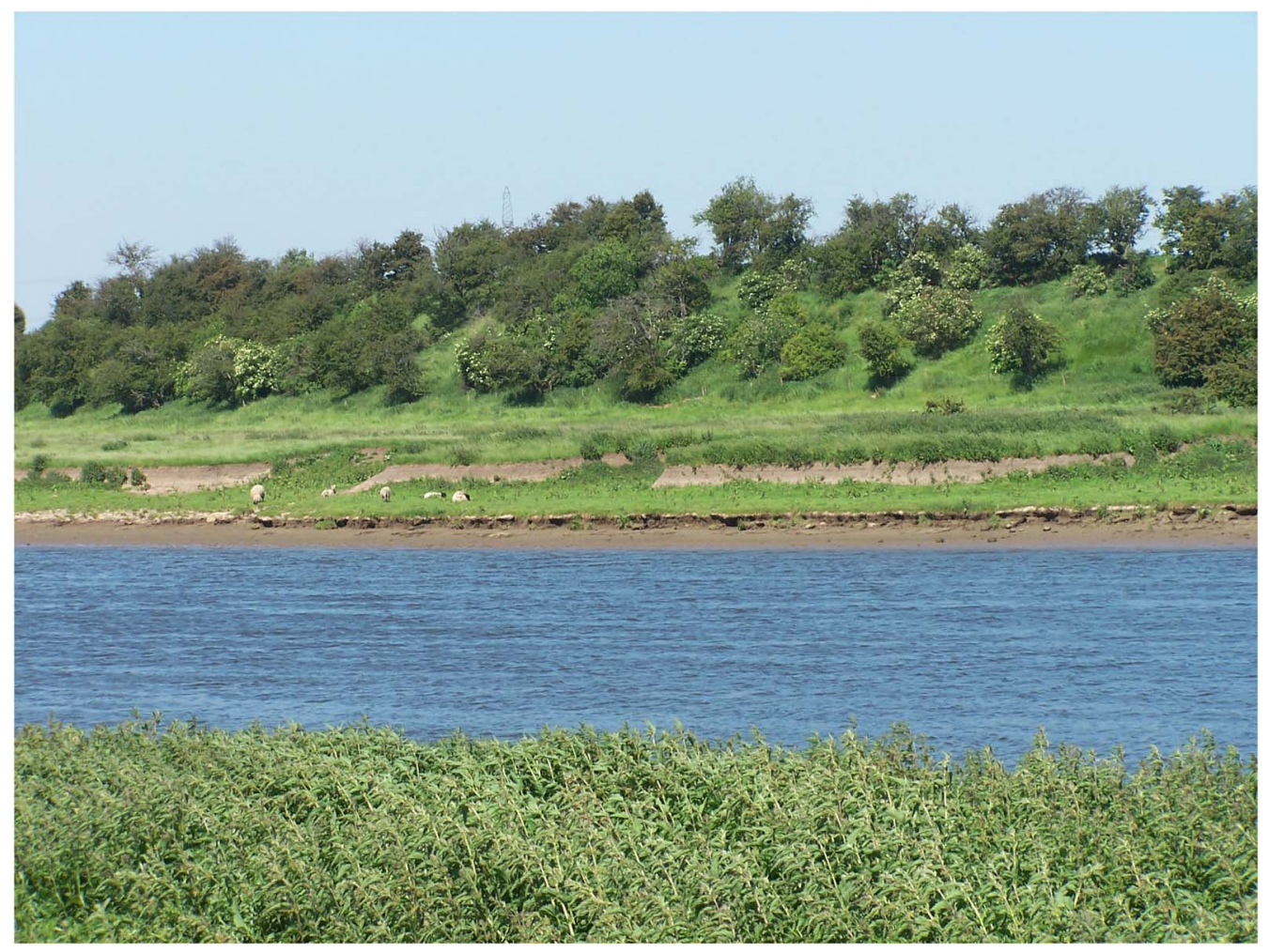

Fig 4. A twenty-first-century view looking east across the River Trent to the prominent bluff and the winter camp

chains and ... rested themselves after their toil so that they might be ready for warfare. From that place they undertook unexpected raids, sometimes in ships, sometimes on horseback, and they destroyed all the province'. ${ }^{47}$ The island character of Torksey is supported by its place name, which incorporates the Old English element $\bar{e}$ ('an island; dry ground in fen, raised land in a wet area') alongside a personal name of debated etymology, but probably Old English Turoc. ${ }^{48}$ Alternatively, the 'island' element may have referred not to the site of the camp, but to the raised ground on which the present village stands, bounded by the Foss Dyke and the Trent, and a band of low-lying wetland to the east, where thirteenth-century sources record 'Brampton Marsh' and 'Torksey Marsh'. ${ }^{49}$

A magnetic gradiometer survey was conducted over 26.9 ha within the site. ${ }^{50}$ This initially took the form of two 6om-wide transects, which traversed the site north-south and west-east, although the survey area was expanded where there was the clearest evidence for archaeological features (fig 5). The most striking anomalies were found in the centre of the transect, where the data indicate a post-medieval rabbit warren and a complex of rectilinear enclosures located

47. Nelson I991, 95, I85; Purcell 2015, 48.

48. Torksey is first recorded as Old English Tureces iege ('Turoc's island'), although later spellings are all consistently 'Turc's island' (eg et Turces ige, in Turcesige): Cameron and Insley 2010, I22-6.

49. Barley 1964, I66; Cole I906, 476.

50. Brown 2012a. 


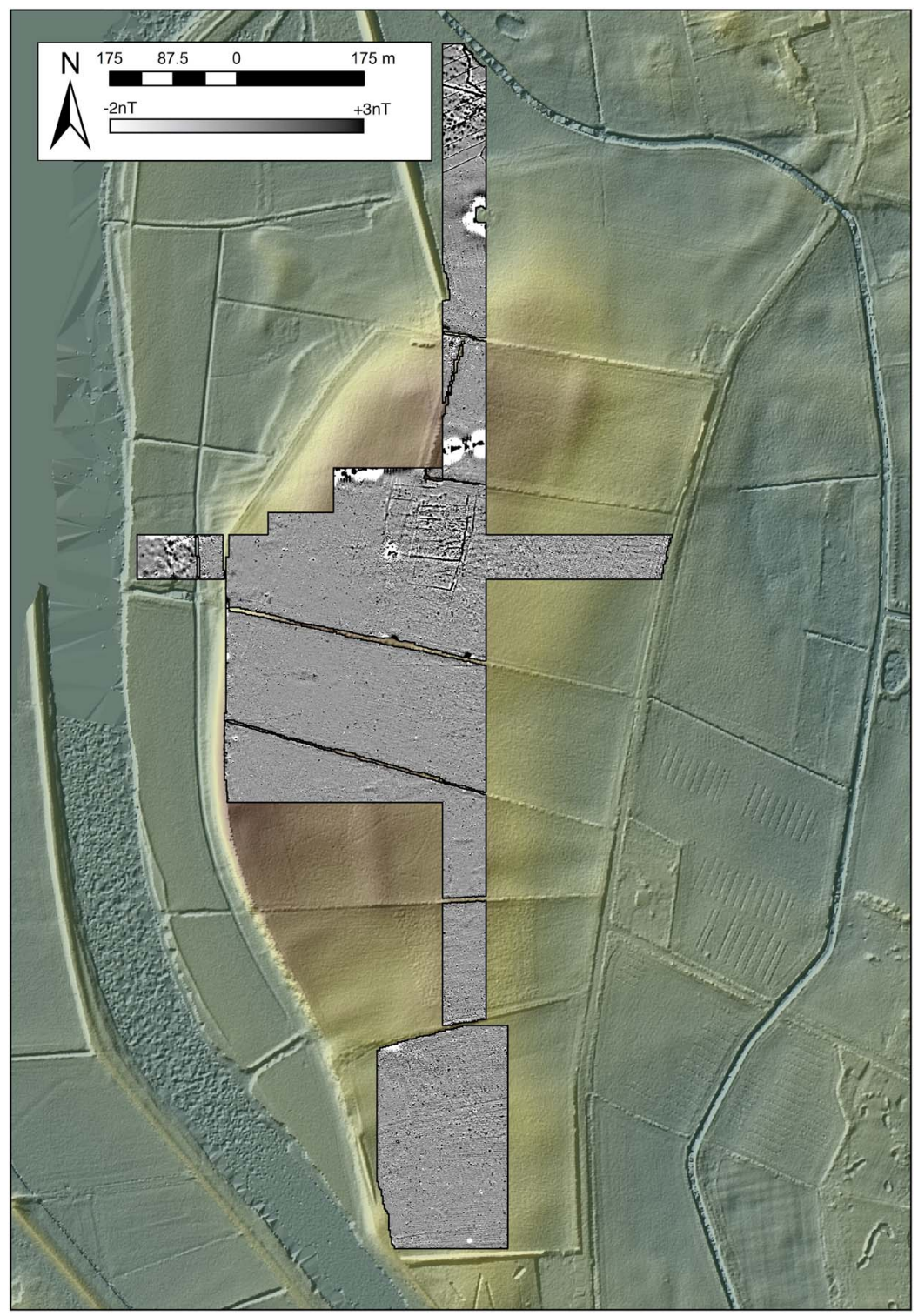

Fig 5. The area of the winter camp, overlaid with the results of the magnetometer survey

towards the northern end of the ridge of high ground that forms the 'island' on which the winter camp was based. These enclosures are characteristic of a Romano-British settlement, incorporating rectilinear ditched enclosures, possible droveways and discrete pits; they are interpreted as a farmstead or similar (fig 6). This interpretation is reinforced by concentrations of Roman pottery found across this area during fieldwalking, as well as by the distribution of Roman metalwork recovered by the detector survey (see fig I2). The location provides a 360-degree view of the surroundings, including Lincoln, Marton, the Trent and Till Bridge Lane, which led to a crossing over the river opposite the former Roman town at Littleborough 


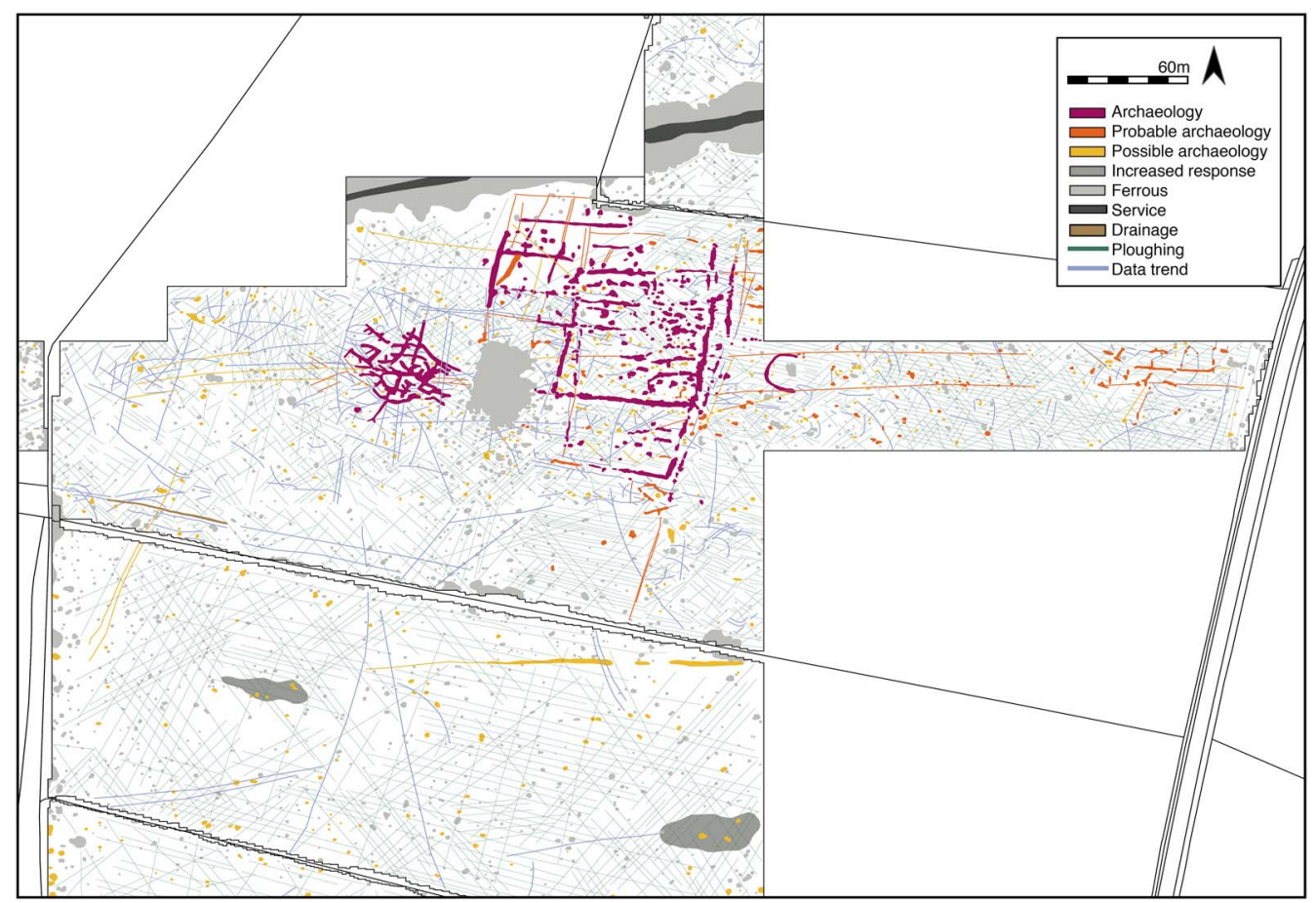

Fig 6. Geophysics interpretation of the central area showing the Roman farmstead (centre) and rabbit warren to the west

(Nottinghamshire), c 3.5 km further north. ${ }^{5 \mathrm{I}}$ There is little indication of any Roman activity within the area of the later village of Torksey, ${ }^{52}$ although pottery kilns of the second and third centuries have been excavated south of the Foss Dyke. ${ }^{53}$

Our geoarchaeological survey demonstrated that considerable build-ups of windblown sand, a part of the Lincolnshire Coversands deposit, blanket the winter camp, up to $3-4 \mathrm{~m}$ in depth. ${ }^{54}$ The coring programme identified the location of former sand dunes, many of which were probably flattened by the first century AD. Analysis of pollen from peat deposits east of the winter camp suggests that woodland clearance accelerated in the Romano-British period, probably associated with the establishment of the farmstead identified by the magnetometer survey. By the time the Vikings arrived in $872-3$, most of the former dunes probably appeared as wide mounds of sandy ground interspersed with the terrace gravels and clay mudstone. ${ }^{55}$ It is suspected that the deposits of windblown sand, which have continued to build up and move since the Viking Age, have obscured detection of archaeology that, even under ideal conditions, can be expected to demonstrate comparatively weak magnetic contrasts with the surrounding soil. Such deposits may, however, have positive implications, ensuring the survival of the archaeology intact beneath the reach

5I. Riley et al 1995.

52. Barley 1964, I72; Mahoney-Swales and Perry 2014.

53. Oswald 1937.

54. Stein 2013; that windblown sand was characteristic of the Torksey landscape had been noted by Barley 1964, 167.

55. Stein 2013. 


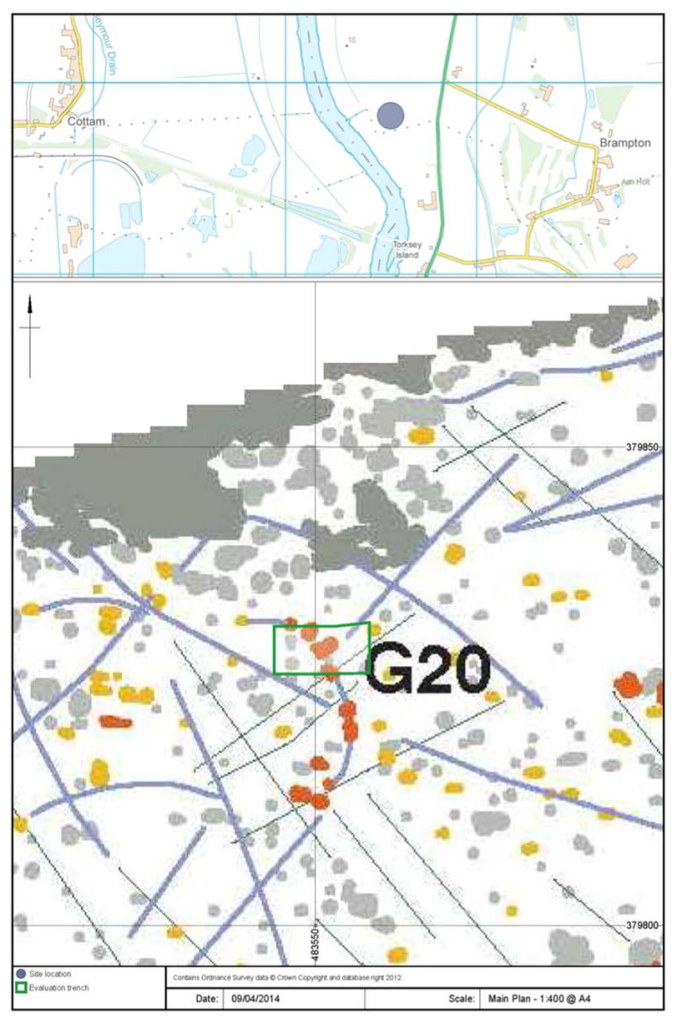

Fig 7. Geophysics interpretation of part of the southern area showing possible anomalies and the location of the TORKI3 test trench (green rectangle)

of the plough. Indeed, one of our test excavations, intended to assess a line of magnetic anomalies identified in the gradiometer survey (fig 7), revealed that silty sand extended to a depth of $1.98 \mathrm{~m}$ below the modern ground surface (fig 8), with a gaming piece, fishing weight and buckle found at a depth of more than $0.5 \mathrm{~m} .{ }^{56}$ OSL dating demonstrated that this deposit had begun to form in the second century AD, and continued to build up in subsequent centuries. The gradiometer survey found no evidence of a defensive ditch, such as that detected with excavation and geophysical techniques at Repton. ${ }^{57}$ It is, of course, conceivable that any such ditch at Torksey was masked by windblown sand, but such a defensive measure may have been unnecessary when one considers the naturally defensible location of the site.

\section{THE METALWORK ASSEMBLAGE}

The windblown sand contains one of the richest assemblages of early medieval finds known from the British Isles. It is estimated that over the last twenty years some seventy metal-detector users have been working the site of the winter camp. The majority 


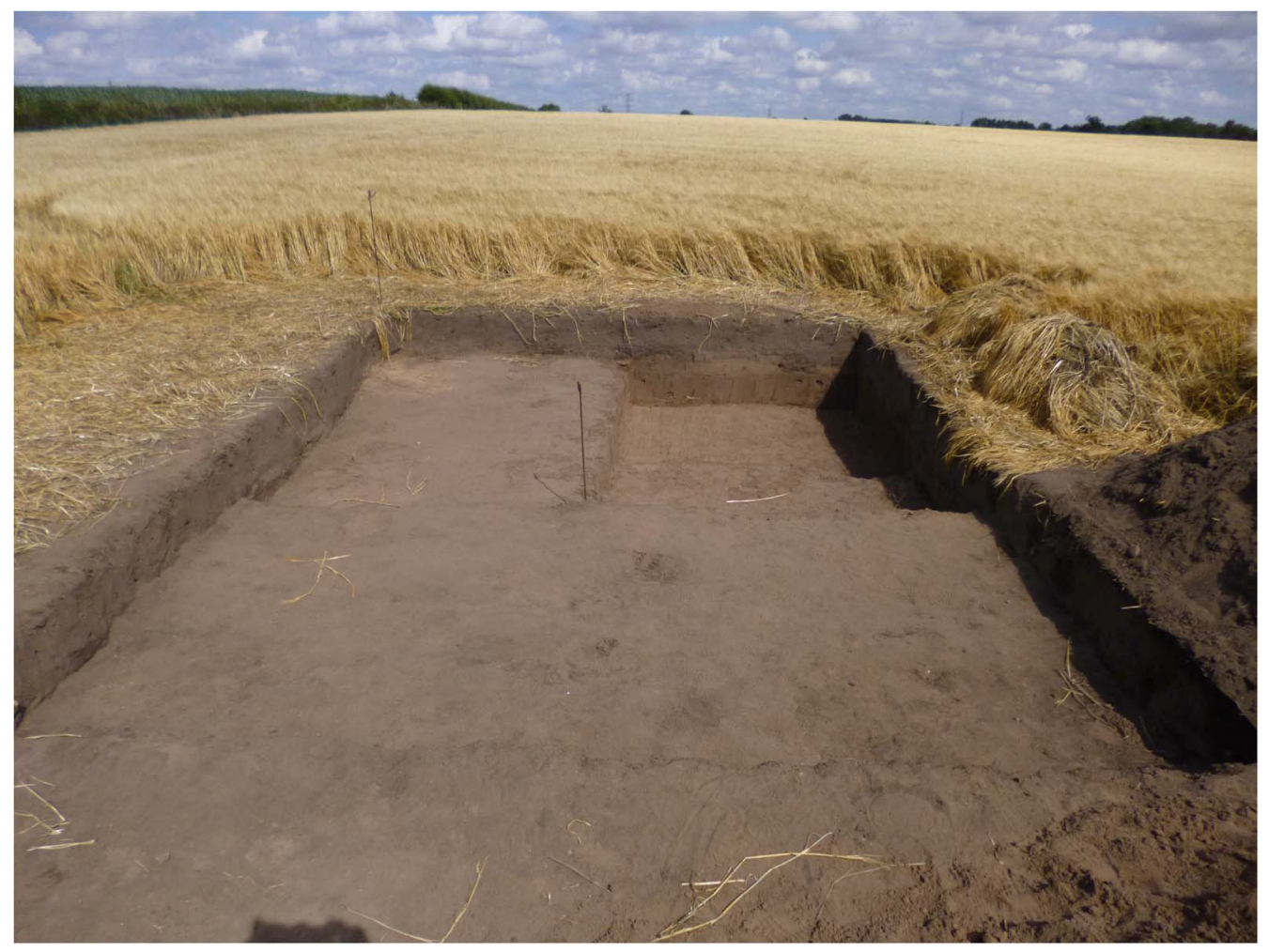

Fig 8. The TORKI3 test trench looking east

of finds are in private collections, although some have been sold online. Many have been logged by the PAS and, given the wide area from which the detectorists have been drawn to Torksey, objects have been reported to a number of finds liaison officers, including those in Sheffield, Derby, Lincoln, Scunthorpe and York. A major task of the assessment has been to update the catalogue of finds provided by Blackburn and to develop a database of all I,572 known finds recovered before August 2015 (table I)..$^{58}$ The largest proportion ( 36 per cent) has been logged by the PAS; 8 per cent are in the Fitzwilliam Museum, Cambridge; 24 per cent are in a variety of other locations, including Lincoln Museum and private collections; and a growing number (currently 22 per cent) are from our own metal-detector survey. The site of the winter camp continues to be subject to modern agricultural practices, including deep ploughing, which regularly brings fresh objects to the surface. Nonetheless, the current landowners are in favour of controlling the detecting and access is now limited to a small number of detectorists, who have been logging the location of their finds with hand-held GPS. Since 20I I all new finds have been plotted. Although there is a scatter of Roman and medieval finds (as is common in most areas of Lincolnshire), the majority of objects (58 per cent) are early medieval (fig 9). Around 38 per cent of these finds are copper alloy, with 37 per cent lead, 20 per cent silver and very small proportions of gold and iron (fig IO). Apart from the under-representation of iron, which is not generally collected by the detectorists, the sample appears to be broadly representative of the

58. Blackburn 20I i; Hadley and Richards 2016a. 


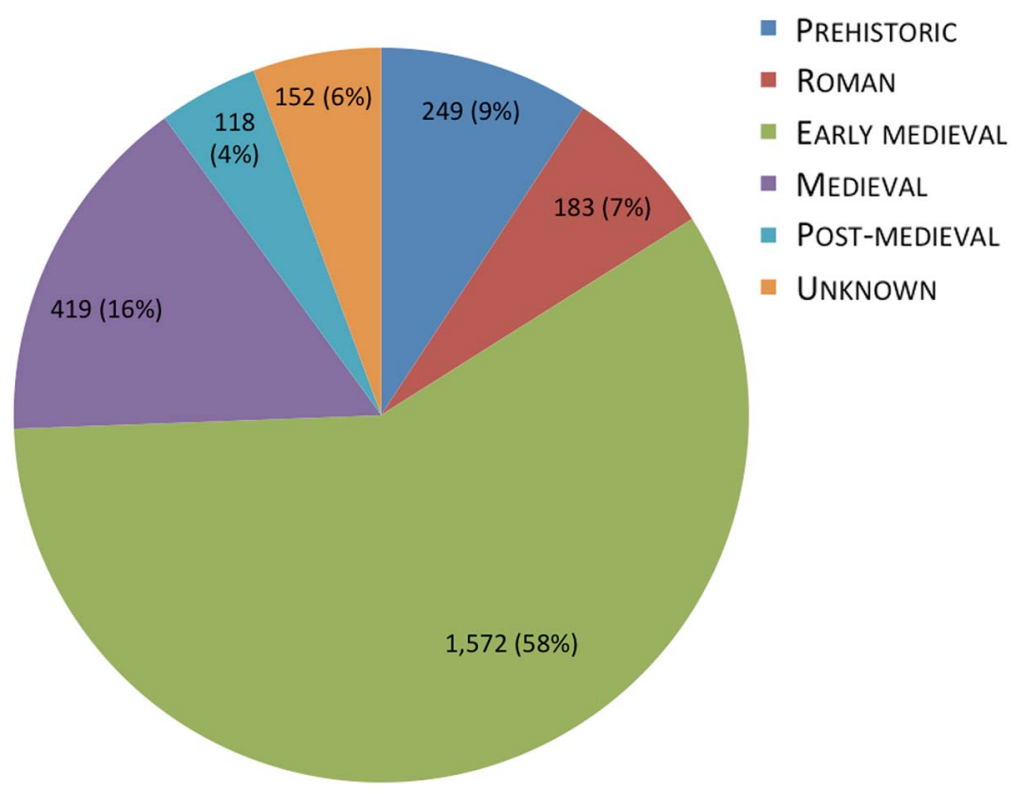

Fig 9. Finds by period

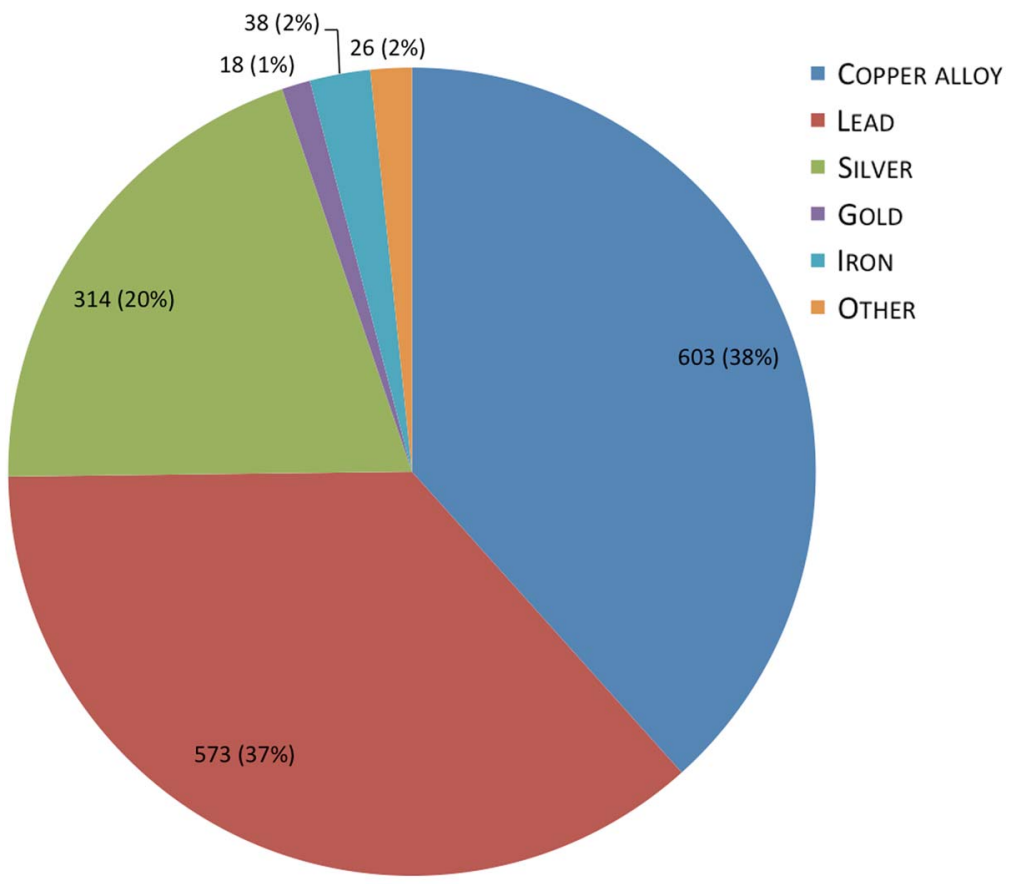

Fig Io. Early medieval finds by material 
Table I. Early medieval finds recovered by metal detector from the winter camp at Torksey (to August 2015)

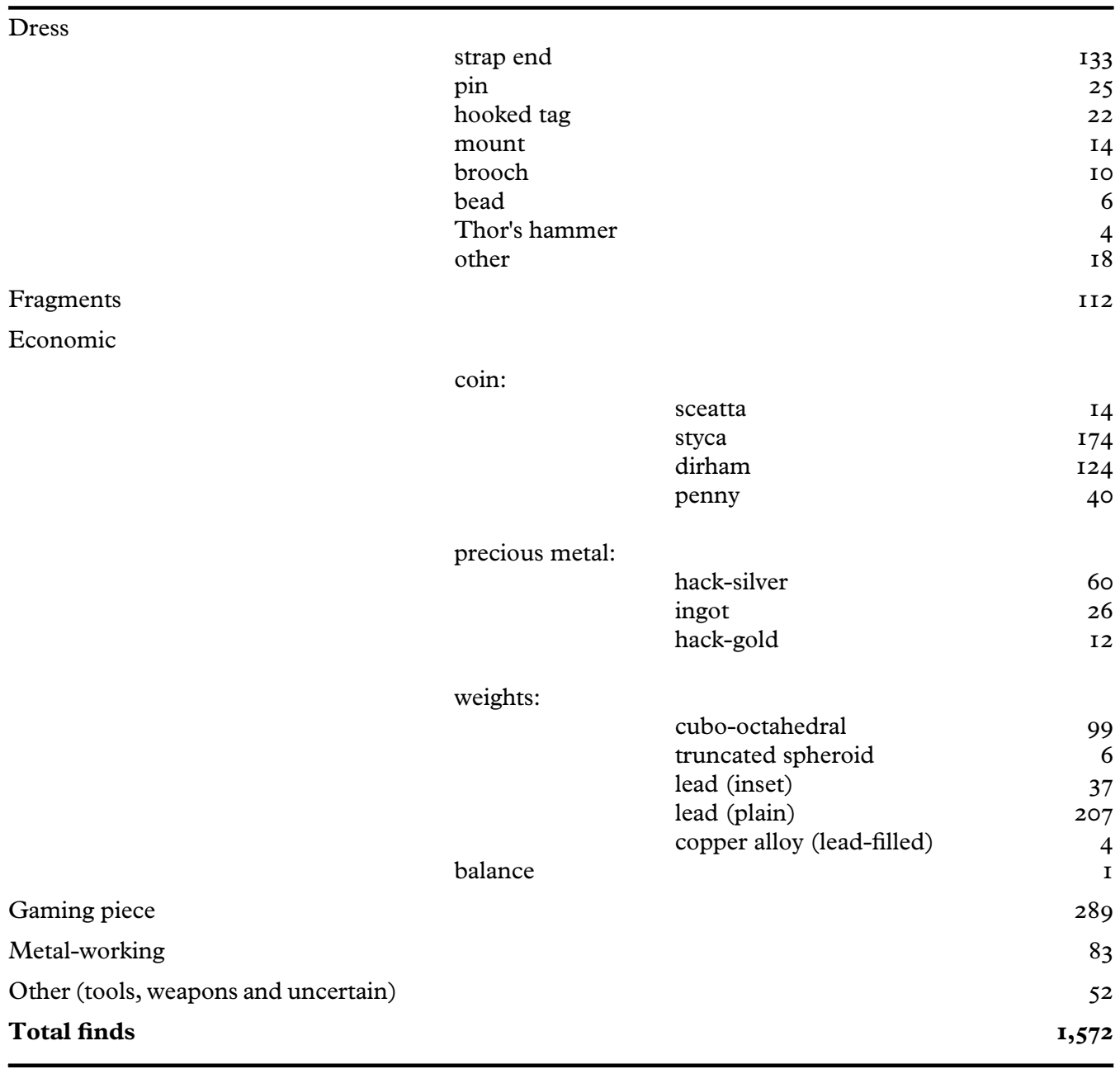

metalwork present on the camp, particularly as the proportions are consistent between different detectorists.

The distribution of early medieval finds plotted during our detector survey (fig II) shows widespread activity across each of the six fields identified as comprising the Viking camp. While the second southernmost field appears to have fewer finds, the survey here has so far been constrained by the cropping regime. Similarly, although distributions of finds by type so far indicate undifferentiated activities, the overall number of geo-referenced finds is still relatively small. Nonetheless, the area of the Roman farmstead, as revealed through geophysics, is certainly confirmed by the distribution of Roman finds (fig I2). The only possible indication of zoning of activities during the overwintering comes from the distribution of lead gaming pieces (fig I3), which cluster towards the northern part of the site and may provide the best indication of domestic areas, although we can map the find-spots of only twenty of more than 280 pieces recovered. 


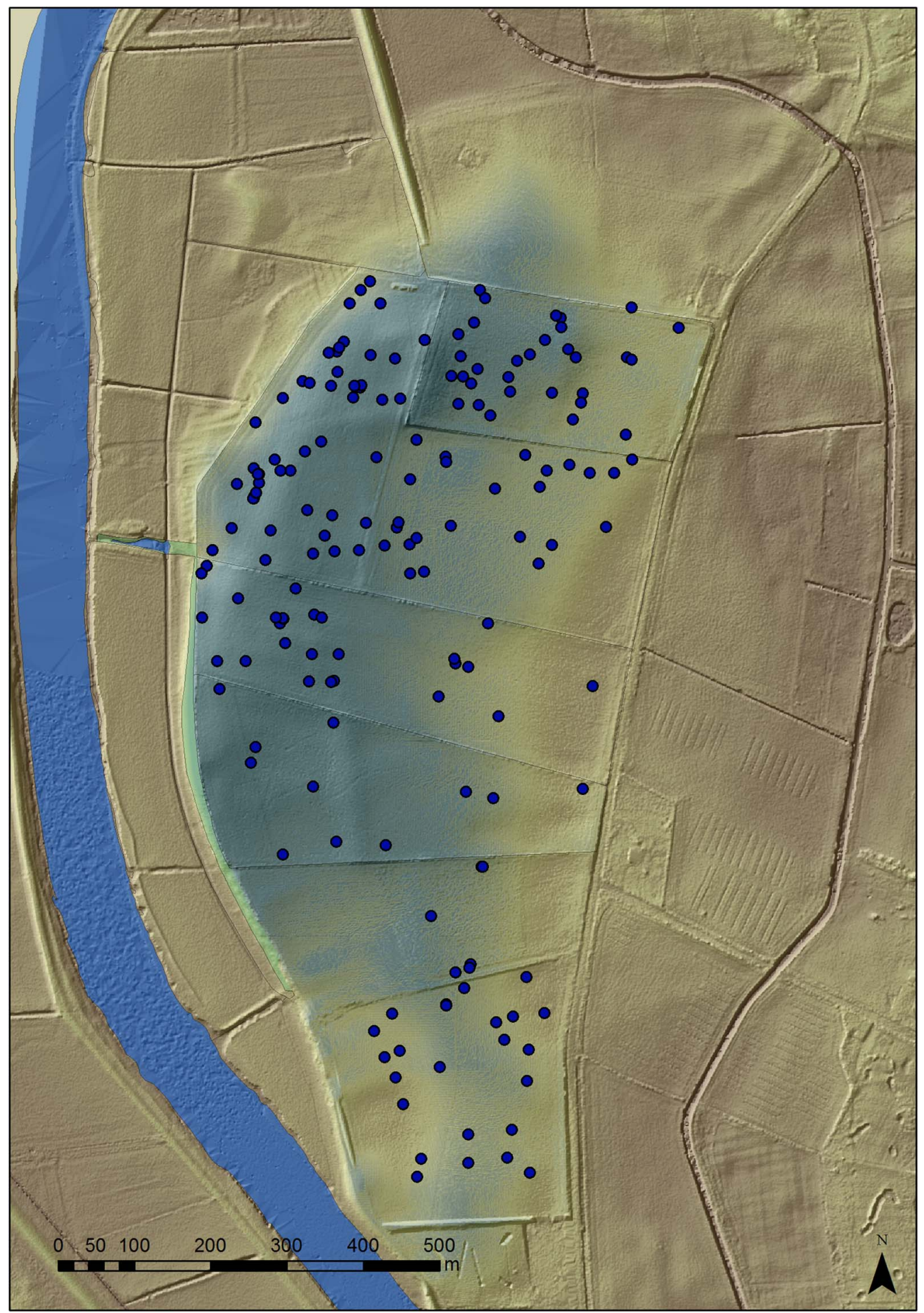

Fig II. Distribution of the early medieval finds 


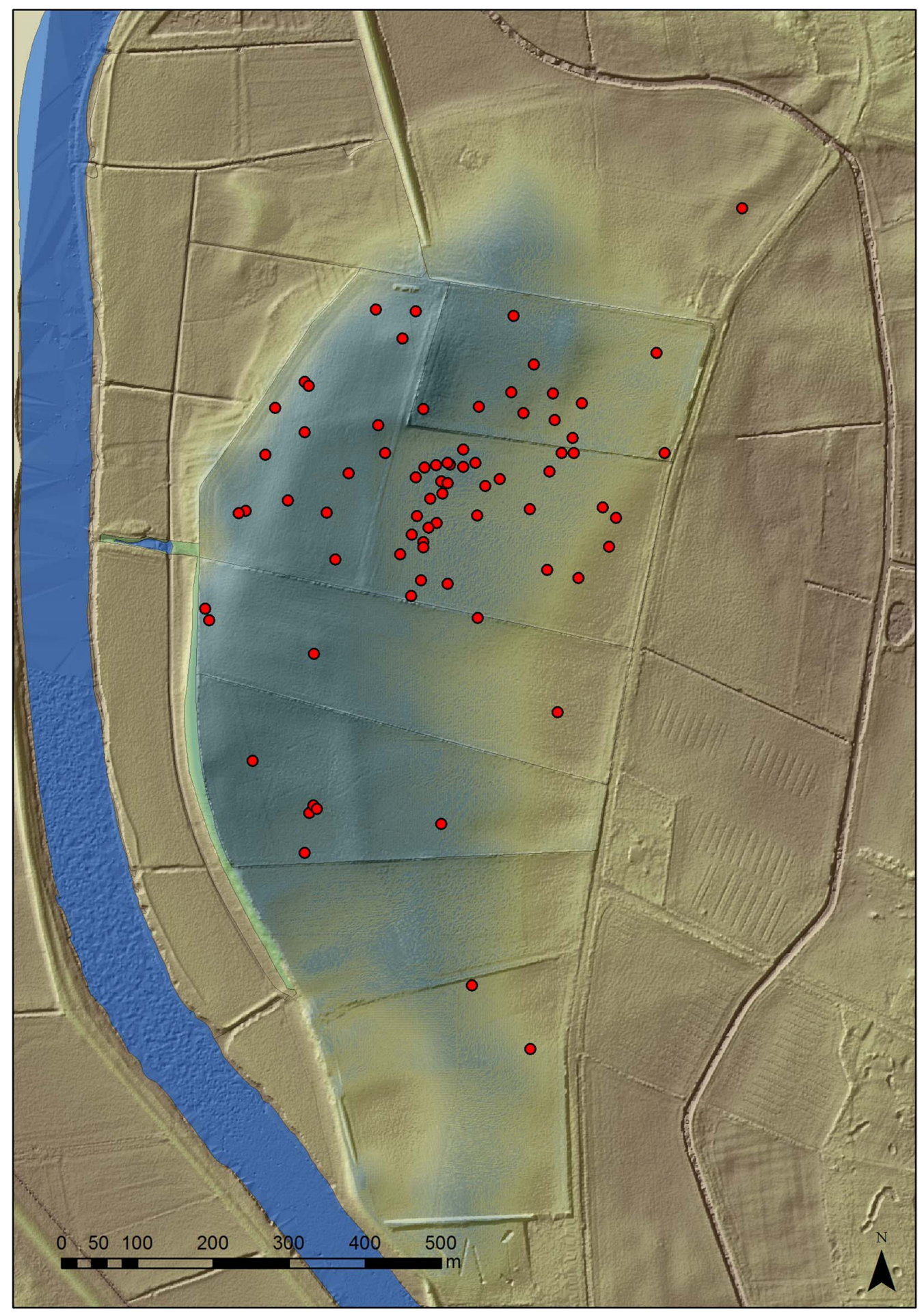

Fig I2. Distribution of the Roman finds 


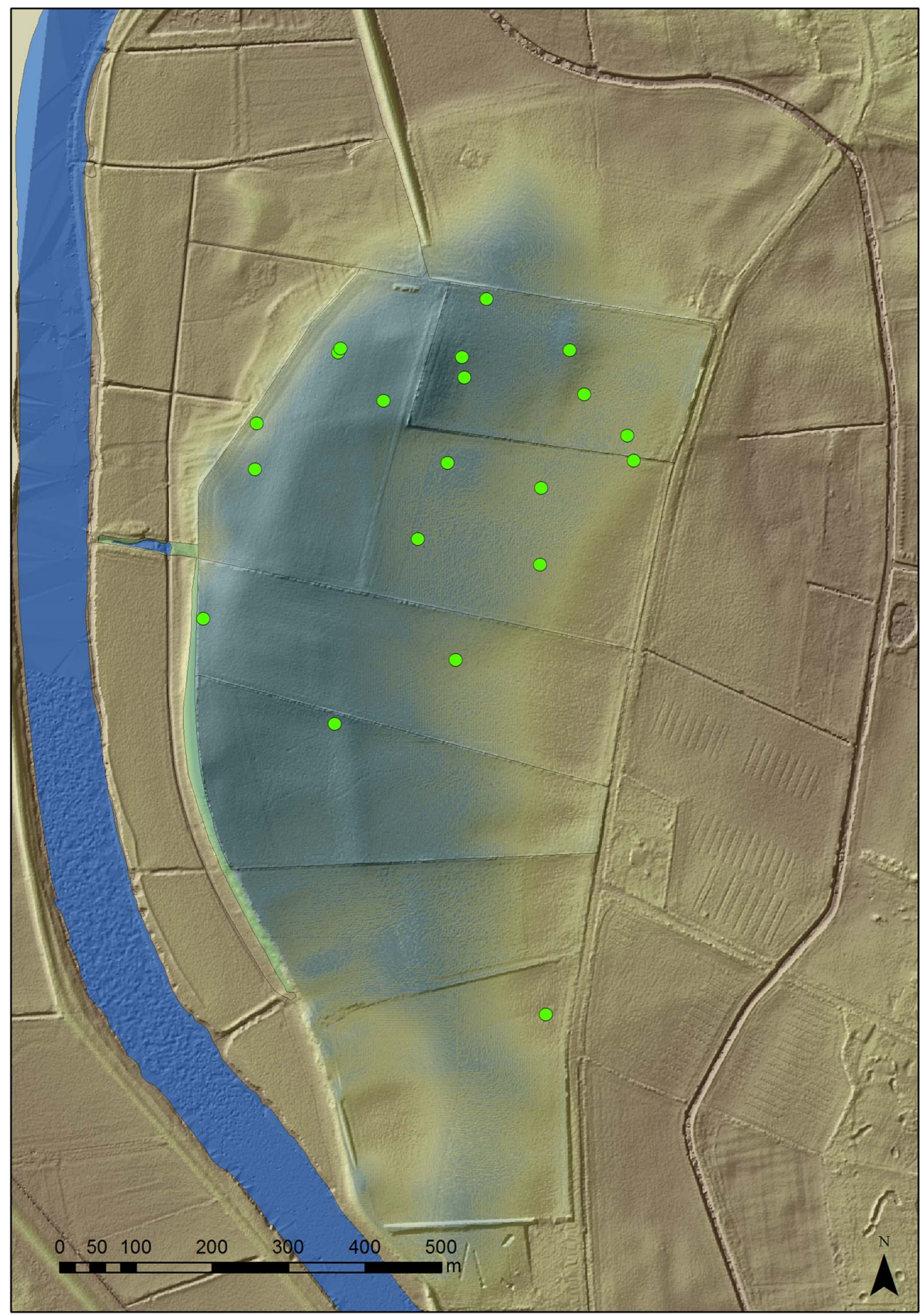

Fig I3. Distribution of the lead gaming pieces 


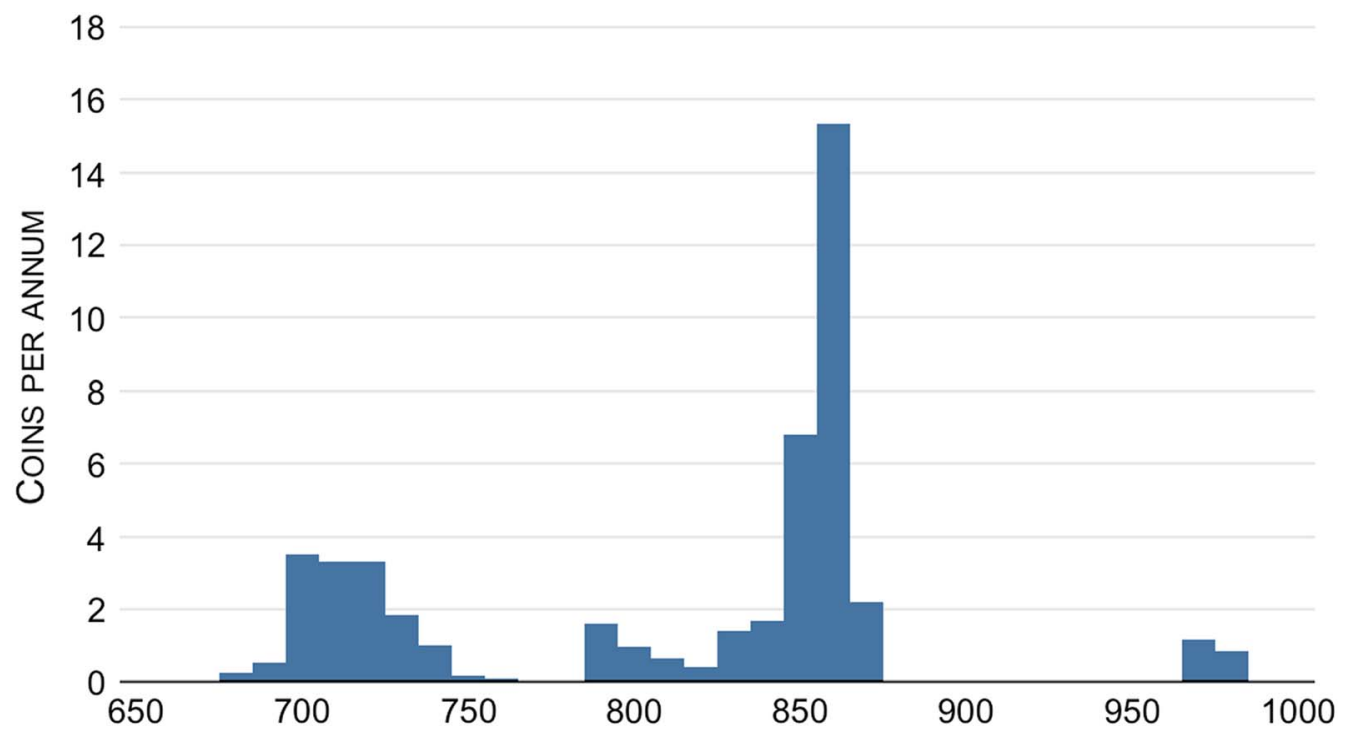

Fig I4. The age structure of the Anglo-Saxon coins, excluding stycas, found at Torksey

\section{DATING THE CAMP}

It is the metalwork and, specifically, the coinage, that allows the assemblage to be dated so precisely and which confirms this as the site of the Viking winter camp of 872-3. More than 350 early medieval coins have been recovered, including forty English silver pennies, with a notable concentration from the 860 s and early 870 s (fig I4), which is striking given that coin finds of the early ninth century are generally more prolific than those of the middle and later parts of the century. ${ }^{59}$ Remarkably, there are also more than 170 Northumbrian copper-alloy stycas, which did not circulate widely outside Northumbria and are generally only recovered in Lincolnshire as single finds. ${ }^{60}$ Most of these were struck in the 840 , particularly during the reign of Aethelred II (840-4, 844-8) of Northumbria. There are also eleven late stycas of Osberht (died 867), probably dating towards the end of Anglian Northumbria. The concentration of stycas at Torksey suggests that they had remained in circulation and had been brought there directly from Northumbria, from where the Great Army had retired to Torksey. ${ }^{61}$ Indeed, stycas are increasingly being identified in Scandinavian contexts in Britain, including settlements, hoards and burials, and ninety stycas have been recovered from Aldwark. ${ }^{62}$

There are also I24 dirhams from Torksey, the largest concentration on any insular site (fig I5). These had all been cut into smaller fractions, indicating that they had been retained for their silver content rather than their monetary value. ${ }^{63}$ These dirhams had clearly been brought to England from the Middle East via Scandinavia, and similar

59. Blackburn 20II, 225.

60. Pirie 2000; Abramson 2016.

6I. Whitelock I96I, 47; Williams 20I5, 99.

62. Williams 2015, 99, II3.

63. Blackburn 20II, 229-30. 


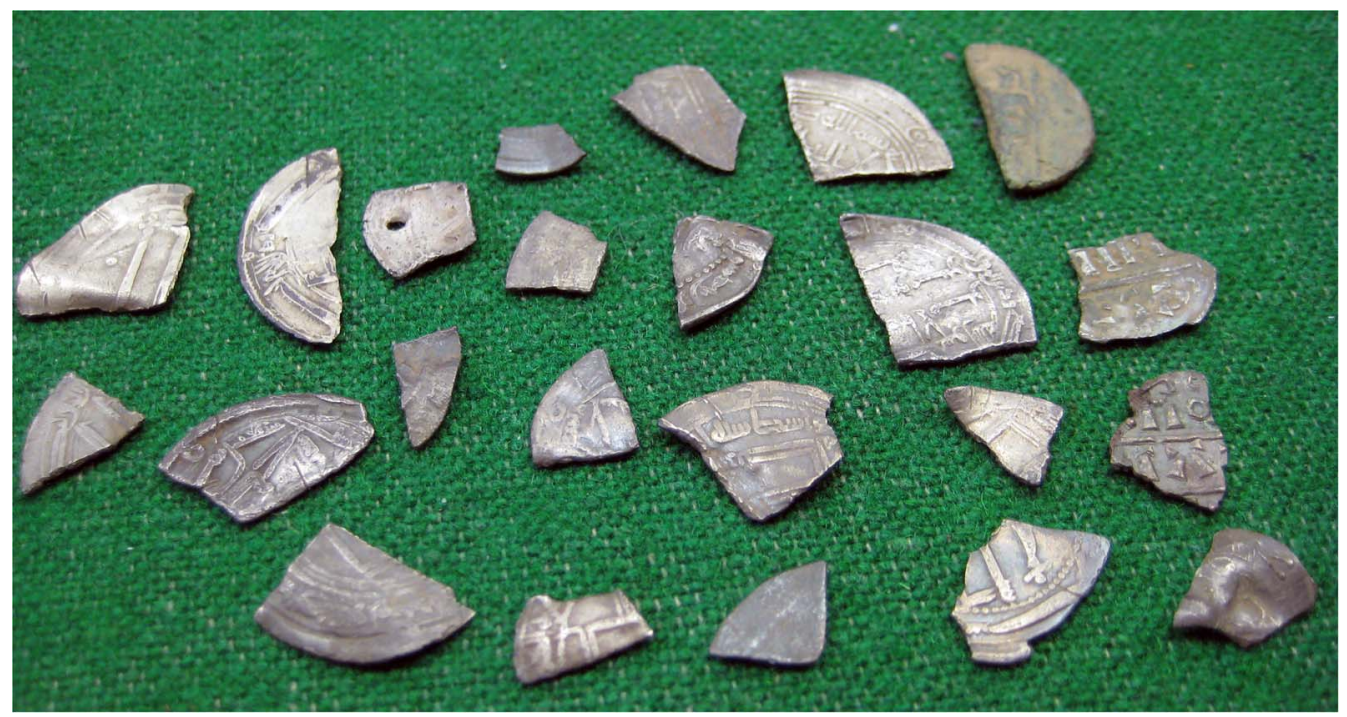

Fig I5. Some of the Islamic dirhams found at Torksey. Photograph: (C) Fitzwilliam Museum, Cambridge

concentrations of dirhams have been found at Scandinavian trading centres such as Birka (Sweden) and Kaupang (Norway). ${ }^{64}$ Indeed, there is growing evidence for large amounts of Arabic silver flowing into the Baltic in the 860s and 870s, and the date profile of the dirhams is similar to that from Torksey, although the sudden break in the late 860 s at Torksey is not reflected at the Scandinavian trading sites, which continued to receive dirhams into the mid-tenth century. ${ }^{65} \mathrm{~A}$ similar span of dates to that at Torksey, comprising both relatively recent and considerably older coins, occurs when dirhams - admittedly in much smaller numbers - are found in hoards in England. ${ }^{66}$

The latest dirhams from Torksey have a terminus post quem in the late 860 , post-dating the arrival of the Great Army in England, which indicates continued contact with Scandinavia during the years of campaigning. The English silver coins have an end-date in the early 870 , and they are likely to have been lost close to their date of production, as there is no evidence for pecking to test for quality. Archibald has argued that the most likely context for the introduction of pecking, first demonstrated in hoards dated to after $c 890$, was the reform of coinage in the mid-870s, when the silver content of new issues was increased, yet earlier issues continued to circulate. ${ }^{67}$ Allowing for the time it would have taken for the dirhams to reach England, they appear to have an end-date remarkably similar to that of the English silver coins in the early 870 s (fig I6). In summary, it is clear that the early medieval coins can only have been brought to the site by the Great Army, given the combination of silver coins of the 860 s and early 870 , dirhams used as bullion and the exceptional concentration of stycas outside Northumbria. 


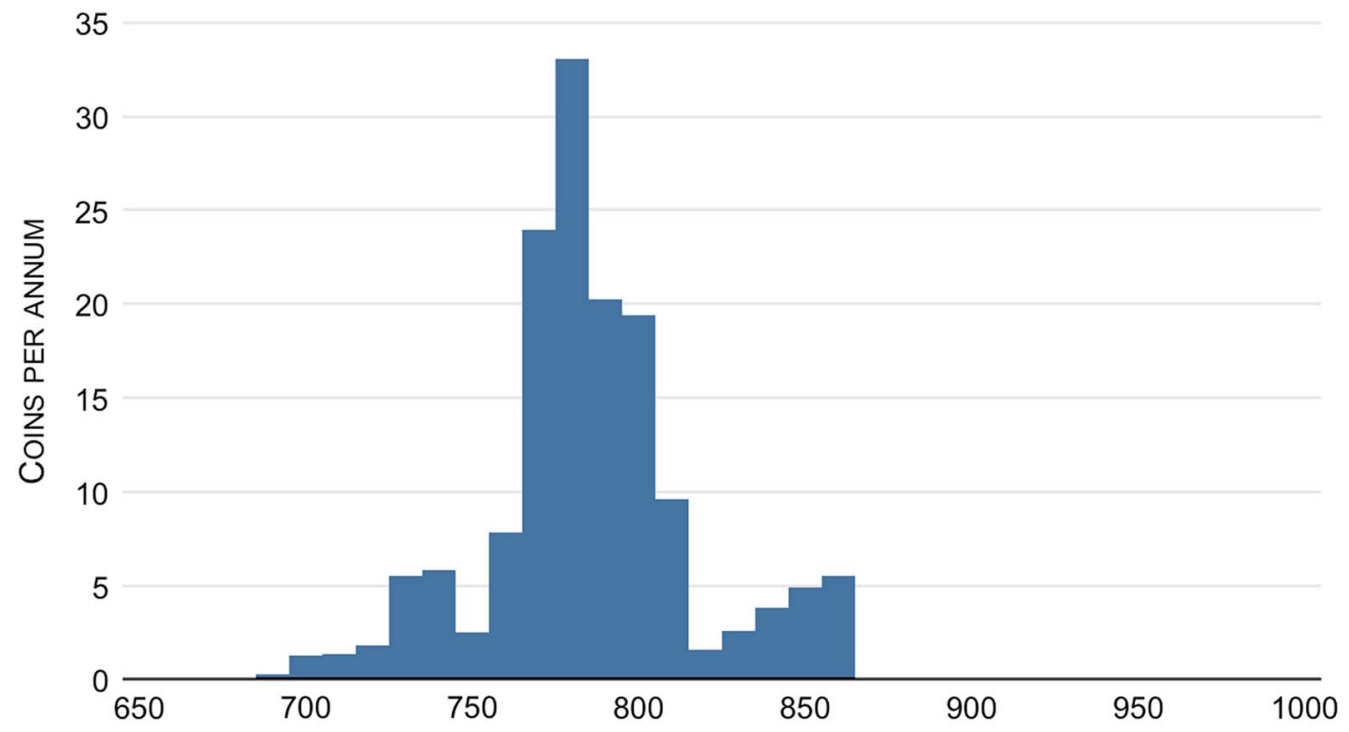

Fig I6. The age structure of the dirhams found at Torksey

A handful of Middle Anglo-Saxon finds and a few late tenth-century dress accessories have been recovered from the same fields, but in insufficient amounts to suggest significant, if any, earlier or later settlement. Fourteen late seventh- to early eighth-century sceattas have been found, but this is a far smaller assemblage than is generally associated with Middle Anglo-Saxon trading sites. The character of the vast majority of the other metal artefacts is consistent, as we shall see, with them having been brought to the site, or produced there, by the Great Army. We are confident, therefore, that the exceptional assemblage of finds from Torksey largely represents a single year of activity, which may be linked exactly to the overwintering of 872-3 recorded in the Anglo-Saxon Chronicle.

\section{ACTIVITIES IN THE CAMP}

At first sight the amount of metalwork recovered from the camp seems remarkable as the reflection of a single overwintering, yet it is clear that in certain circumstances single events can lead to massive accumulations of material; the detritus left by more recent armies - or even on modern music festival campsites - reminds us how easy it is to mislay items in muddy and trampled fields. The fact that even gold and silver objects were not recovered at the time indicates the sheer quantity of portable wealth that must have been collected by the Army. The assemblage is invaluable in contributing to our understanding of what a Viking army did while it was overwintering, including trade and exchange, coin production and metal processing, as well as leisure activities.

\section{Trade and exchange}

That Viking armies were accompanied by individuals involved in trade is suggested by the finds from Torksey. This should not be a surprise, as it is revealed in continental texts. For example, the Annals of St-Bertin record that in 873 a Viking army besieged by Frankish forces 


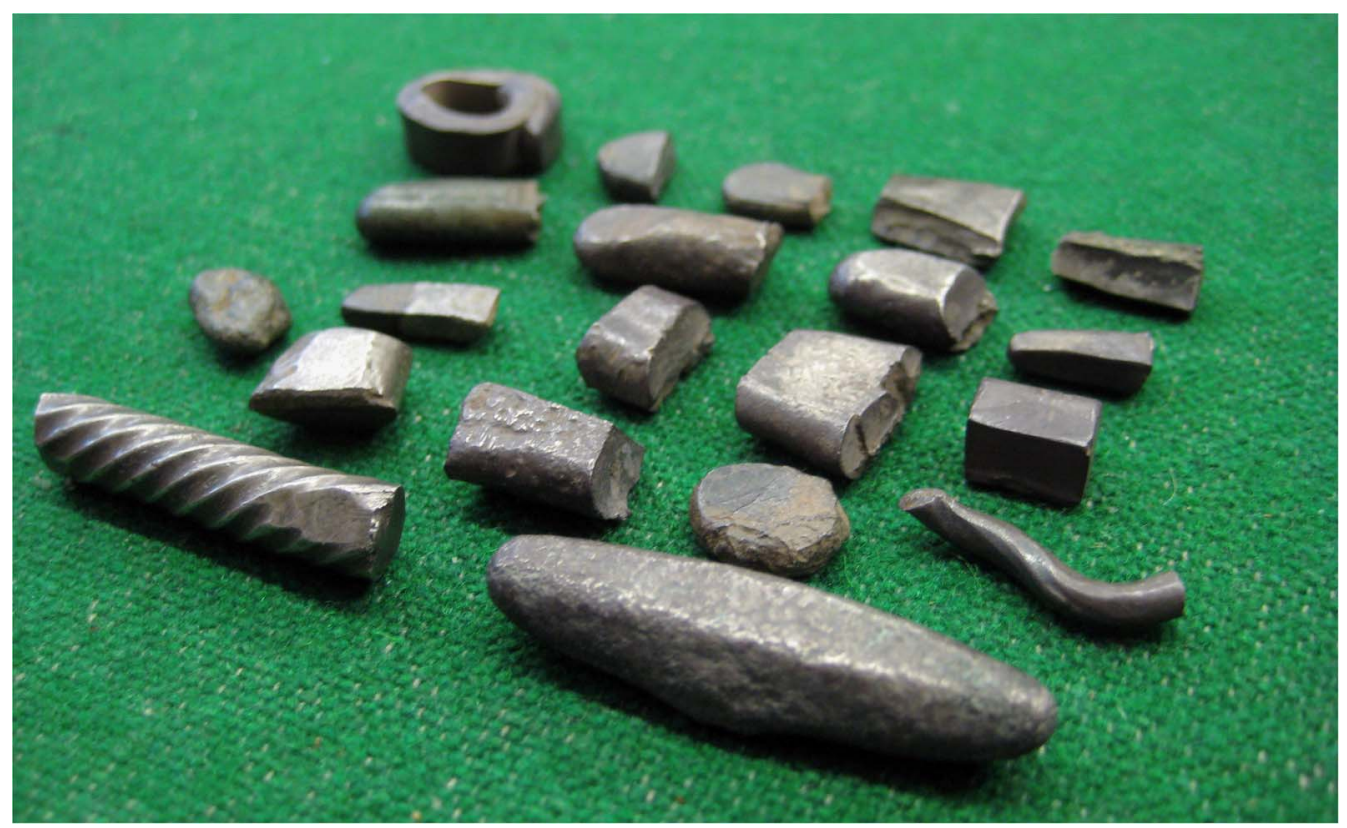

Fig 17. Some of the silver ingots and hack-silver found at Torksey. Photograph: (C) Fitzwilliam Museum, Cambridge

at Angers was permitted to hold a market on an island in the Loire before departing in February. That armies were associated with trading is reinforced by the entry in the Annals for 876, which describes the 'traders and shield-sellers' that followed the army of Charles the Bald. ${ }^{68}$

It is apparent that there were multiple economies operating alongside one another at Torksey. There was evidently an important role for bullion, as is clear from the fragmented state of the dirhams, the presence of sixty pieces of hack-silver (fig I7), and the mixed profile of the coins - from three Anglo-Saxon kingdoms, the continent and the Arabic world. In this context, Anglo-Saxon, Irish and Scandinavian fragmentary decorative silver jewellery can also be interpreted as having been used for monetary exchange. ${ }^{69}$ Taken together, this evidence reinforces the impression of the operation of a bullion-based economy that emerges from the many Viking silver hoards of the late ninth and early tenth centuries. Most of these are a generation later than the finds from Torksey, but an exception is the hoard from Croydon (Surrey), consisting of hack-silver, ingots and c 250 coins from Mercia, Wessex and the continent, plus three dirhams. This has been dated to $c 872$ and associated with the movement of the Great Army to London in the winter of 87I-2. ${ }^{70}$ More recently, a hoard from Watlington (Oxfordshire), comprising I86 coins, seven items of jewellery and fifteen ingots, has been dated to the late 870 s following the defeat of the Viking army at Edington. ${ }^{71}$ Hack-silver, silver ingots and imported coins have also been found at Woodstown and Aldwark, suggesting that a

68. Nelson I99I, I83-5, I97.

69. Blackburn 20II, 230-5.

70. Brooks and Graham-Campbell 2000.

7I. <http://www.britishmuseum.org/about_us/news_and_press/press_releases/20I5/viking_hoard_ found.aspx $>$ (accessed 6 Sept 2016). 


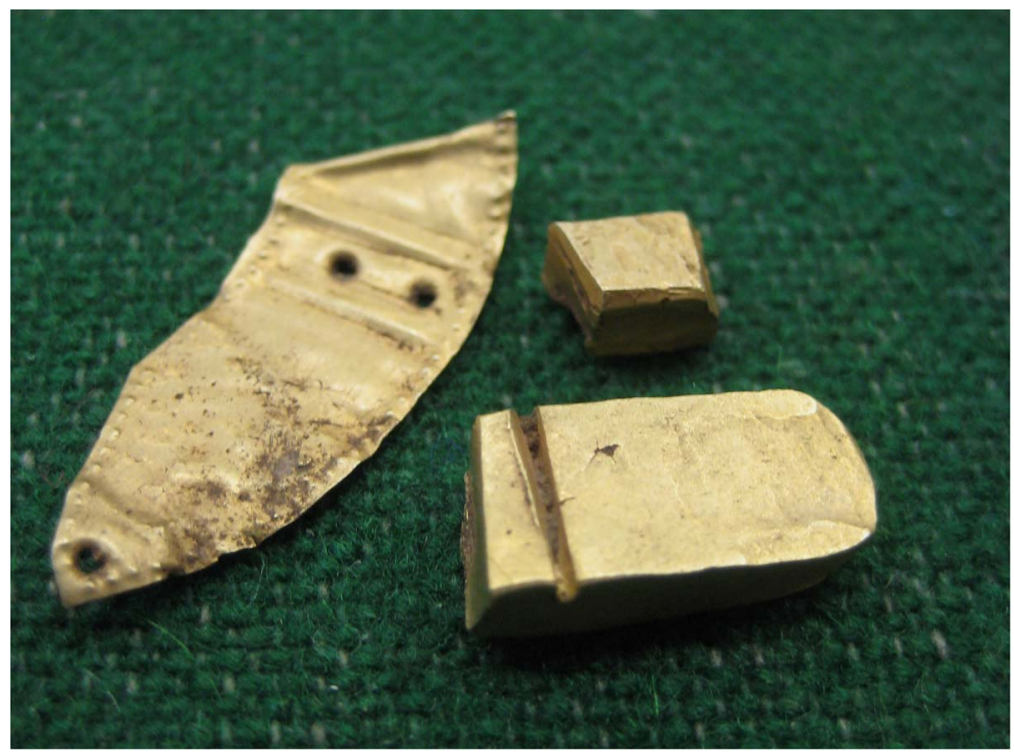

Fig I8. Some of the hack-gold from Torksey. Photograph: (C) Fitzwilliam Museum, Cambridge

bullion economy also characterised these Viking camps. ${ }^{72}$ Recent analysis of a rural settlement at Cottam (Yorkshire) has revealed late ninth-century use of bullion, indicating Scandinavian settlement, which endured at the site into the tenth century. ${ }^{73}$

Twelve pieces of hack-gold have been recovered at Torksey, which are very unusual finds (fig I 8). Several pieces had been chisel-cut from gold ingots, although one twisted piece may have been cut from an arm- or neck-ring. Two cut gold solidi - one Frisian, the other Carolingian - may also have been bullion. This is an important insight into Viking activity because, unlike hack-silver and silver ingots, gold in any form rarely occurs in Viking Age hoards in Britain, and it has been suggested that this is in part because of its greater rarity and in part because it may have played more of a role in status display than in economic transactions. ${ }^{74}$ However, the remarkable concentration of gold finds from Torksey does seem to suggest the use of gold in such transactions. This may even help to explain the unique discovery of fake hack-gold from the site, in the form of goldplated copper alloy, including a fragment of an ingot and two sections cut from square rods. ${ }^{75}$

It is possible that copper-alloy artefacts were also being used as a form of low-value bullion. Indeed, there are twelve copper-alloy ingots from Torksey (fig I9), one of which has the transverse hammering often visible on silver ingots, and this may hint at a system of value where copper was of some importance in exchange. ${ }^{76}$ Such a practice is not reflected in Viking Age hoards in England, but copper-alloy ingots from eastern England are

72. Williams 2015, I09.

73. Haldenby and Richards 2016.

74. Blackburn 2007.

75. Blackburn 20II, 233-4; for recent discoveries of Viking Age gold ingots from East Anglia, see Pestell 2013, 248-9.

76. Blackburn 20II, 235-6. 


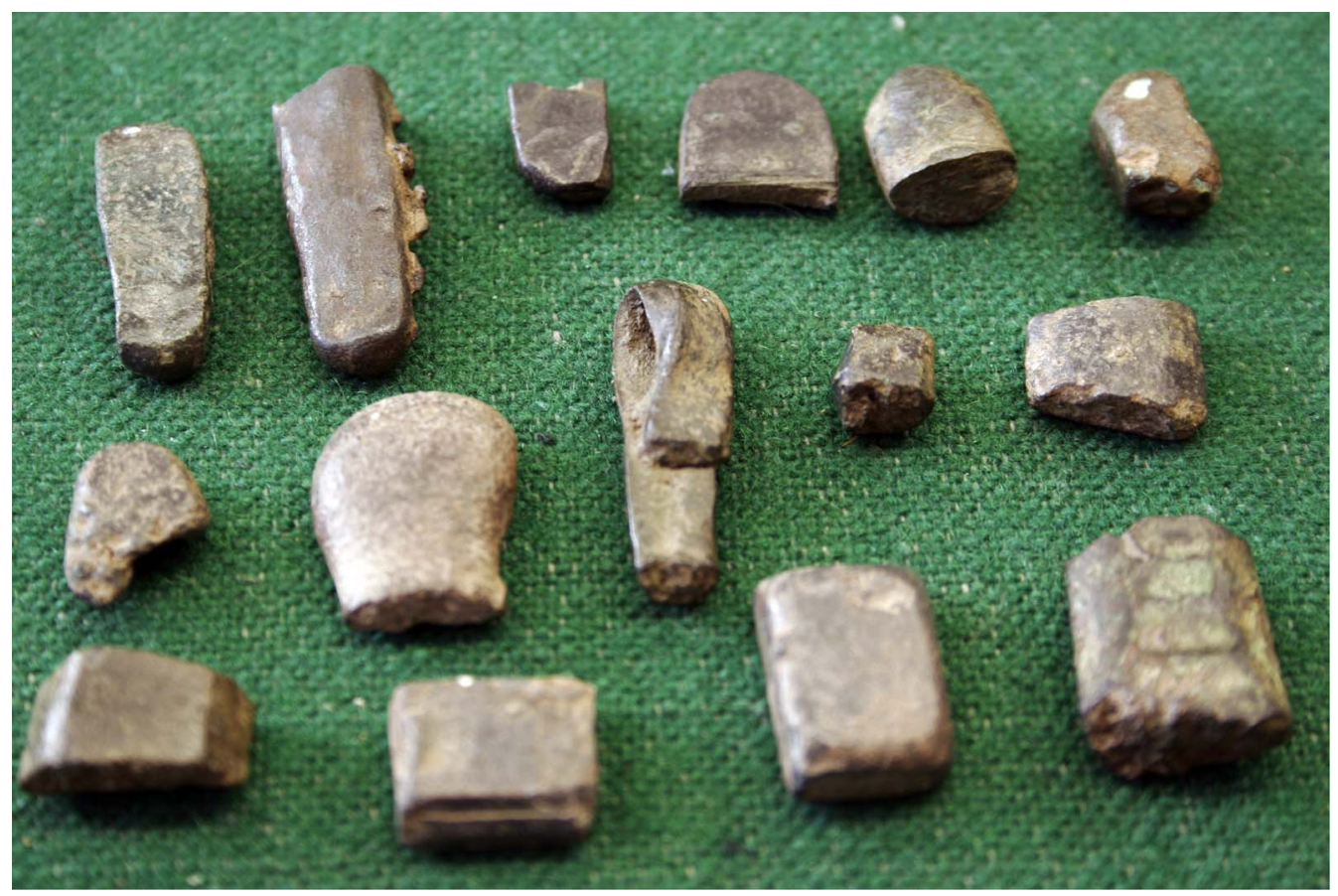

Fig 19. A group of cut copper-alloy ingots (hack-copper) from Torksey. Photograph:

(C) Fitzwilliam Museum, Cambridge

increasingly being identified, some with the distinctive transverse hammering. ${ }^{77}$ There is also some evidence for this economic use of copper alloy more broadly across the Viking world, with ingots found in several hoards (such as one from Spillings on Gotland, which has a terminus post quem of $\mathrm{AD} 874$ ) and stycas found at trading sites in Scandinavia. ${ }^{78}$

A bullion economy required the weighing of the metal, and more than 350 weights have been recorded from Torksey (fig 20). ${ }^{79}$ Nearly one hundred of these are copper-alloy cubo-octahedral weights, and there are also six truncated spheroid copper-alloy weights. Both arguably reflect the design and weight standards of Arabic copper-alloy weights, and similar examples appear in considerable numbers on Scandinavian sites from the 860s and 870s, while there is some evidence, from Birka and Gotland, that they were being manufactured there. ${ }^{80}$ They are increasingly being recognised from sites in Britain and Ireland: Aldwark has produced twenty-four cubo-octahedral weights, and there is also one from Woodstown, although neither has produced a spheroid weight. ${ }^{81}$ Those at Torksey must represent parts of multiple sets of weights. Our analysis has not identified any

77. Pestell 2013, 249-50.

78. Pettersson 2009; Williams 20II, 354-5.

79. Determining the difference between lead weights and gaming pieces is difficult, but in our analysis solid lead pieces were classed as weights and hollow examples as gaming pieces. This hollow form would have allowed them to be stacked; indeed, one of the Torksey pieces was found inside another.

80. Pedersen 2008, I2I, I32-40.

8I. Williams 20I5, 99, II I; one object from Aldwark may be the iron core from a spheroid weight. 


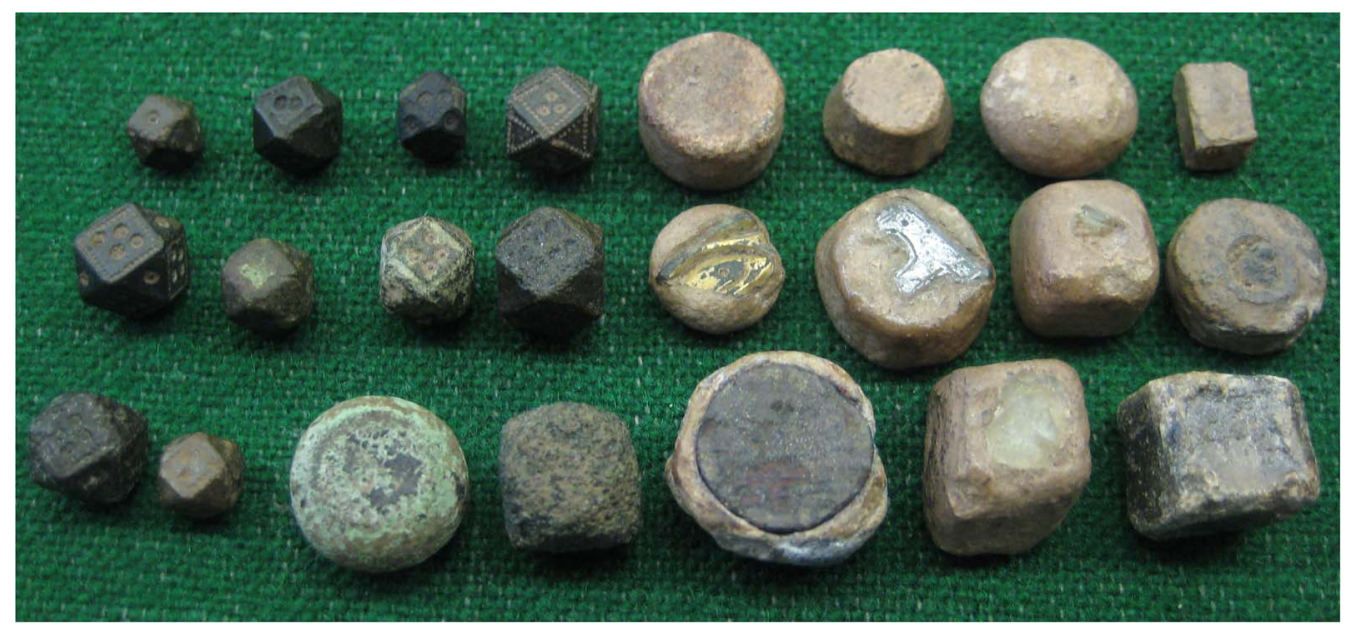

Fig 20. A sample of weights from Torksey, including examples of cubo-octahedral, truncated spheroid and lead inset types. Photograph: (C) Fitzwilliam Museum, Cambridge

consistent weight standards, although the composite nature of the Great Army might account for a diversity of practice. Nearly 250 lead weights have been recovered, thirtyseven of which are inset with decorative metalwork, largely of insular origin. Similar inset lead weights have been found at numerous sites: Aldwark; Woodstown; the settlement at Llanbedrgoch on Anglesey; and in Viking burials at Islandbridge, near Dublin, and at Kiloran Bay, in the Inner Hebrides. Inset lead weights are also found in low numbers in Scandinavia itself, where they are thought to represent the transfer of an insular Viking tradition. ${ }^{82}$ These inset weights seem, therefore, to reflect innovation in the operation of the metal-weight economy, and the production of these weights provides another example of manufacturing during the earliest phases of Scandinavian settlement.

The sheer scale of the precious and base metalwork from Torksey does not, of itself, demonstrate the nature or extent of economic transactions undertaken there, but these are likely to have been diverse. The distribution of precious metals was undoubtedly one of the means by which Viking leaders enhanced their prestige and secured the loyalty of their followers. While the imported dirhams show extensive fragmentation, this is not true of the Anglo-Saxon coins, which may reflect their use within a monetary economy, not simply as bullion. The use of bullion alongside a managed currency has been dubbed the 'dual economy' of the Danelaw, and has been assigned to the period when coins began to be minted for Scandinavian rulers from the 880 s/890s until the 920 , but it now appears that it existed from the very outset of Viking settlement in the west. ${ }^{83}$ The picture that emerges from Torksey is, however, not so much of a 'dual economy' as of multiple metal economies operating simultaneously, with gold, silver and copper alloy all used in both coined and bullion form. ${ }^{84}$

It is unlikely that the Great Army accrued the wealth that is reflected in the finds from Torksey solely through raiding and plunder. The Great Army is repeatedly recorded as having

82. Ó Floinn 20I4, I8I-9I; Williams 20I5, I09-I3.

83. Graham-Campbell 200I.

84. Cf Williams $201 \mathrm{I}$. 
concluded peace treaties during its overwintering, and tribute-taking may have been an element in this process; leases of land by ecclesiastics are known to have occurred in the late ninth century as a means of raising tribute to pay Viking armies. ${ }^{85}$ Slave trading may have been a factor in acquiring wealth, and may ultimately be the origins of the dirhams from the Middle East that Viking armies brought with them. Irish and continental sources record the capture and sale of slaves by Viking armies, and while this is not directly documented in contemporary sources in England, it must have occurred; indeed, the peace treaty between Alfred and Guthrum from the 880 contains a clause in which the rulers agreed not to harbour the runaway slaves from the other's realm. ${ }^{86}$ Slaves may also have been used for labour or to provide sexual services within the camp. The ransoming of hostages may have been another means of acquiring wealth, and hostages were also politically useful. Following the arrival of the Great Army at Repton, the new ruler of Mercia, Ceolwulf, gave hostages and swore oaths that he would be ready 'at the enemy's service' whenever required. The details of the peace made between the Army and the Mercians at Torksey are not provided in the Anglo-Saxon Chronicle, but it may have included similar arrangements. ${ }^{87}$

\section{Coin production}

There is some tentative evidence that the Great Army was minting coins during its campaigns. A strip of lead from Torksey bearing the impression of the die for an imitative gold solidus of Louis the Pious (8I4-40) supports the long-held belief that imitative gold solidi were being minted in England, since a number have been found in eastern England, albeit not from these actual dies. ${ }^{88}$ They seem intended to have served as coins, not pendants, since there is no evidence for suspension loops. A lead impression of a lunette coin of Burgred of Mercia from Torksey (fig 2I) also suggests minting; it appears to bear a blundered inscription, as do 23 per cent of the stycas, which may be an indication that these were Viking imitations. ${ }^{89}$ A plated copper-alloy lunette was evidently a forgery, and one of the dirhams (finds catalogue CM.6oI2010) appears to have a green patina, again suggesting a contemporary forgery, of which a similar example of the early tenth century has been found in York. ${ }^{90}$

Once they had seized control of the Anglo-Saxon kingdoms, Viking rulers, such as Guthrum, began to mint coins, ${ }^{91}$ which is usually regarded as requiring 'an administrative infrastructure to issue them and regulate their use'. ${ }^{22}$ However, the lead impressions of dies and blundered stycas from Torksey suggest that the minting of coinage emerged during the overwintering phase, even before the Viking leaders had adopted the administrative apparatus of Anglo-Saxon kingship. Nonetheless, the boundaries between the use of precious metals in a bullion, monetary and a status-based or 'display' economy can be fluid, and precious metals could easily be melted down and transformed into other forms, whether ingots, coins or display items, such as the silver arm-rings of which fragments have been found at Torksey, along with some evidence for their manufacture. ${ }^{93}$ The decision to mint

85. McLeod 2006, and 20I4, I86-98.

86. Pelteret 1980, I06-7; Holm 1986.

87. Whitelock I96I, 46-7.

88. Blackburn 2007, 69-73.

89. Blackburn 2002, 93-4.

90. Blackburn 20I I, 225; Hall I994, 87.

91. Blackburn 200I; 2005.

92. Blackburn 2007, 72.

93. Williams 2007 , 178 . 


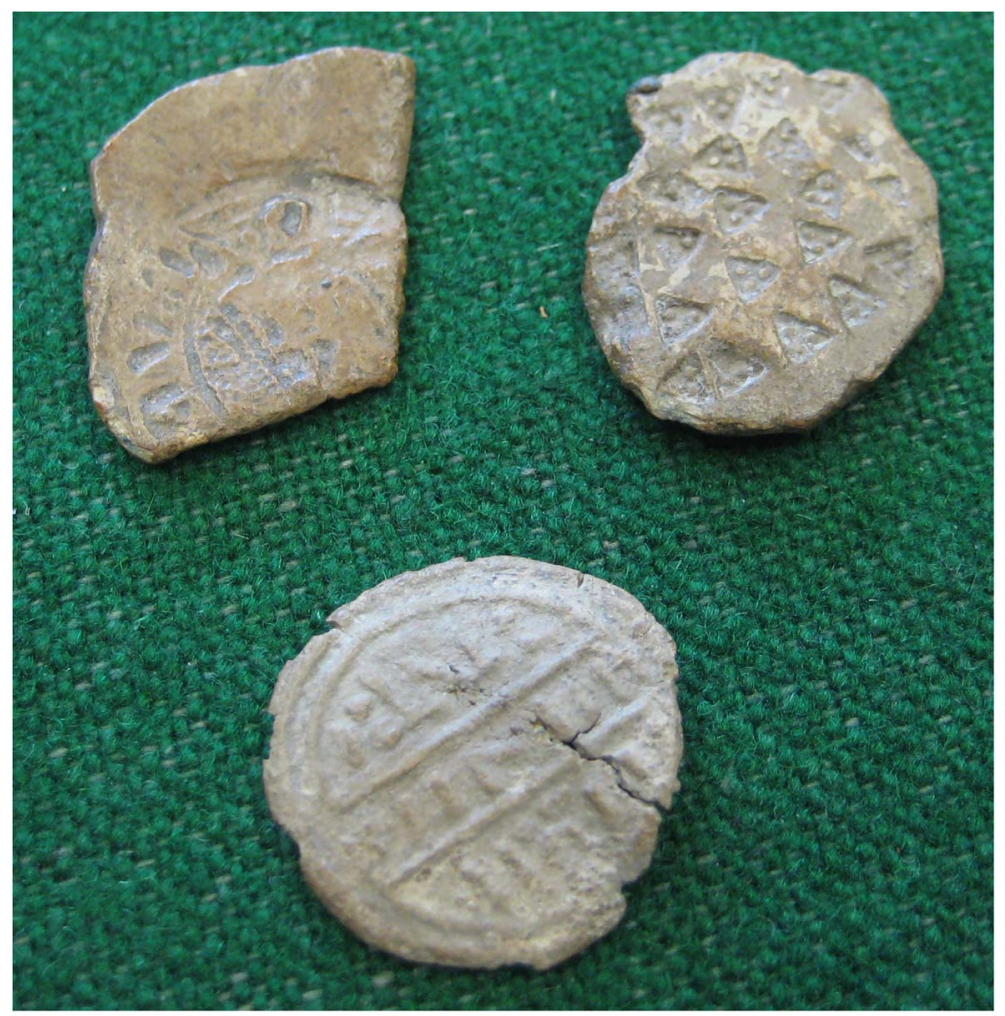

Fig 2I. Evidence of coin and metal production at Torksey. Top left: lead bearing the impression of lunette type A coin of Burgred of Mercia; top right: a lead trial piece for triangular punches; bottom: a lead striking from dies of a lunette type A coin. Photograph: (C) Fitzwilliam Museum, Cambridge

coins is an ideological one, and often an expression of authority on the part of a ruler. ${ }^{94}$ To a Viking army, coins were not necessarily more logical than bullion, but minting of imitations suggests that they understood something of the political as well as the economic value of coinage. The Great Army may have been engaged in minting coins for a variety of reasons: to use coinage in economic exchange locally to buy supplies; to display the aspirations of its leaders in an attempt to establish Viking authority within the Anglo-Saxon kingdoms; and as a response to competition between leaders within the Great Army.

\section{Metal-working and other activities}

Metal was also used in various forms of processing and production. While not capable of being closely dated, melts of gold and silver indicate metal-working, and silver-casting waste has also been recovered from Aldwark and Woodstown, while a high proportion of the cupels and crucibles recovered from Woodstown were used for silver-working. ${ }^{95}$ At Torksey the recovery of three strips of lead on which decorative punches had been tested

94. Ibid, I80-I.

95. Treasure Annual Report 2004, 9I-3; Sheehan 20I4, 206-7; Young 2014, 267-82. 


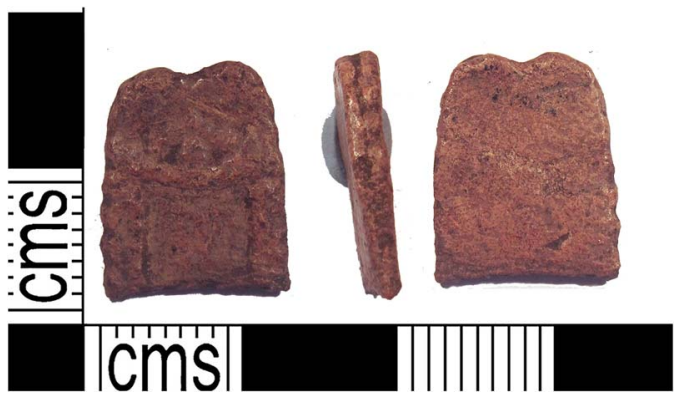

Fig 22. A lead casting for a strap end. Photograph: (C) Fitzwilliam Museum, Cambridge

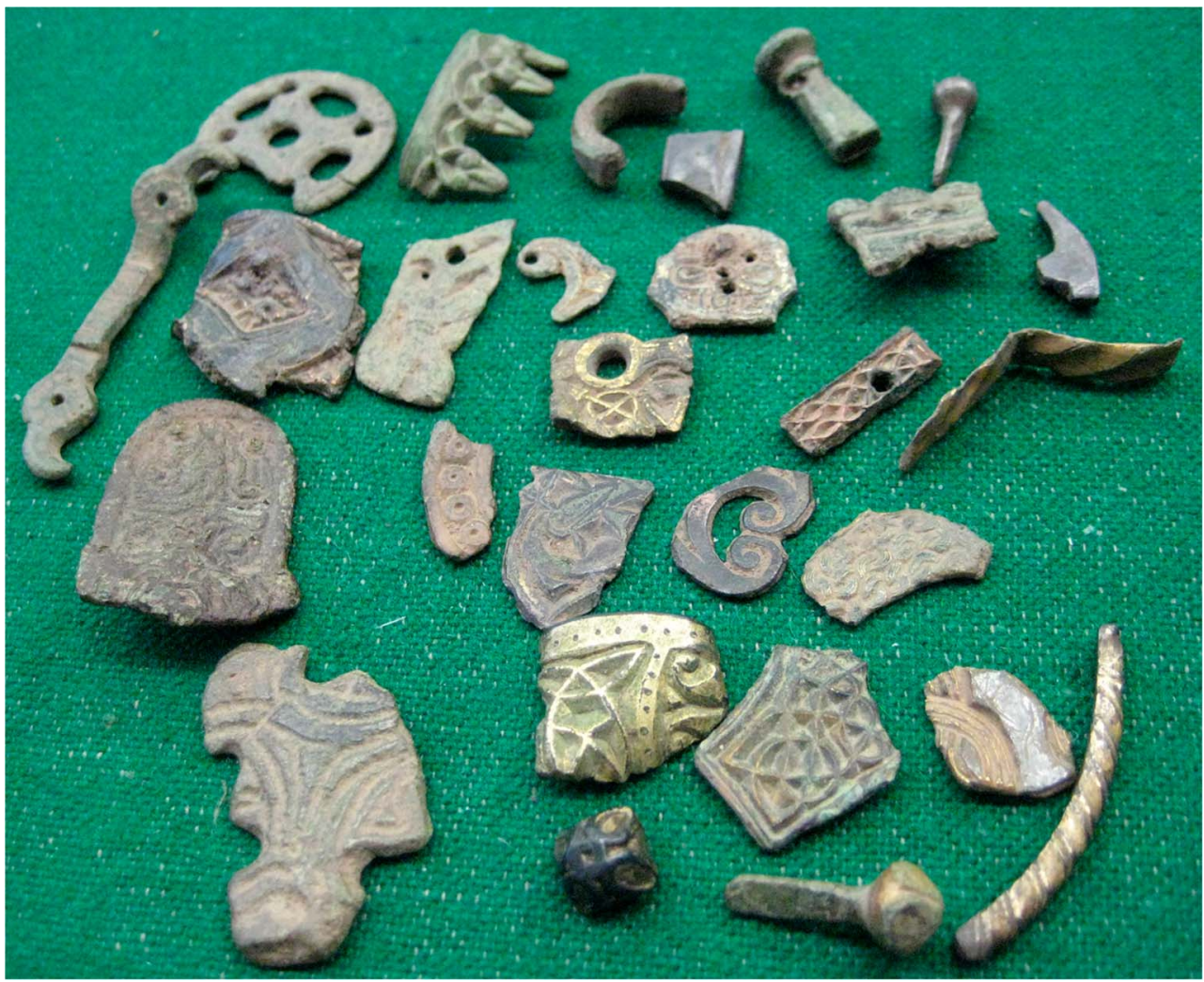

Fig 23. A sample of fragmentary copper-alloy decorative metalwork from Torksey.

Photograph: (C) Fitzwilliam Museum, Cambridge

suggests the production of Scandinavian silver jewellery, such as arm-rings. A fragment of a lead Pressblech die could have been used to impress decoration onto gold foil which was to be applied to other objects. ${ }^{96}$ That base metal-working was also undertaken is supported by the recovery of a lead casting for a strap end (fig 22), copper-alloy and lead melts, and more than 200 fragmentary copper-alloy artefacts (fig 23), which were deliberately

96. Blackburn 20II, 242. 

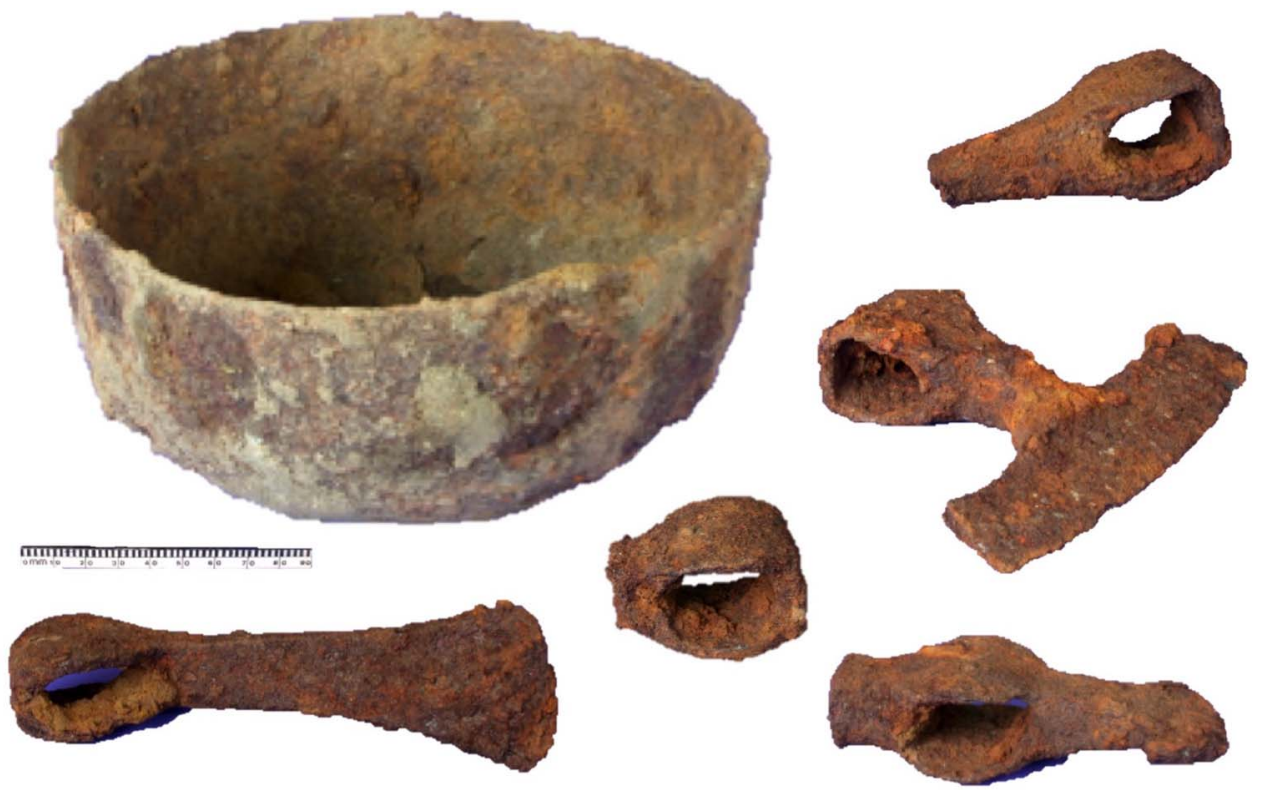

Fig 24. A selection of artefacts from the hoard of woodworkers' tools, including a cauldron, an adze, an axehead and several hammer heads. Photograph: (C) Lincoln Museum

cut, suggesting they were to be melted down. ${ }^{97}$ Some of the fragmentary items may, alternatively, have been intended as insets for the lead weights or other form of display, since a significant minority have been pierced and some have intact rivets. ${ }^{98}$

Although no examples of clench nails have yet been recovered from Torksey, it is very likely that ships were drawn up onto the flood plain below the camp for repair over winter. Indeed, a hoard of iron woodworking tools is believed to have been recovered from the winter camp. ${ }^{99}$ The tools (fig 24), which include four axeheads, an axe hammer, an adze and a two-edged blade, can be dated broadly on typological grounds to the eighth to tenth centuries. If they were used during the overwintering it is notable that they have an Anglo-Saxon form, lacking the distinctive pointed lugs of Scandinavian types, and may reveal the use of Anglo-Saxon material culture, if not labour. ${ }^{\mathrm{IOO}}$ Hoards of iron tools have sometimes been interpreted as ritual deposits; in a Scandinavian context, these are typically found in riverine and marshy environments. ${ }^{\text {IOI }}$ However, a ritual interpretation seems unlikely for the Torksey hoard as the tools are not a complete set for any particular type of woodworking, unlike broadly contemporary iron hoards from Scandinavia. ${ }^{\text {IO2 }}$ The worn and damaged tools were accompanied by some fifteen fragments of iron vessel - mainly bowls, and two tripod stands - suggesting that this was scrap iron ready for reworking; the hoard may therefore provide evidence for both woodworking and iron-working on the site. The general paucity of iron artefacts from Torksey must to a large degree be connected to the under-representation of iron among the reported finds. It is, in

97. An unfinished strap end has also been recovered from Aldwark: Williams 2015, 105.

98. For example, Hadley and Richards 20I6a, finds catalogue CM_I82I_2008.

99. Now in Lincoln Museum.

I00. Carhart 2015.

IOI. Thomas 2008; Raffield 2013.

I02. Carhart 2015. 


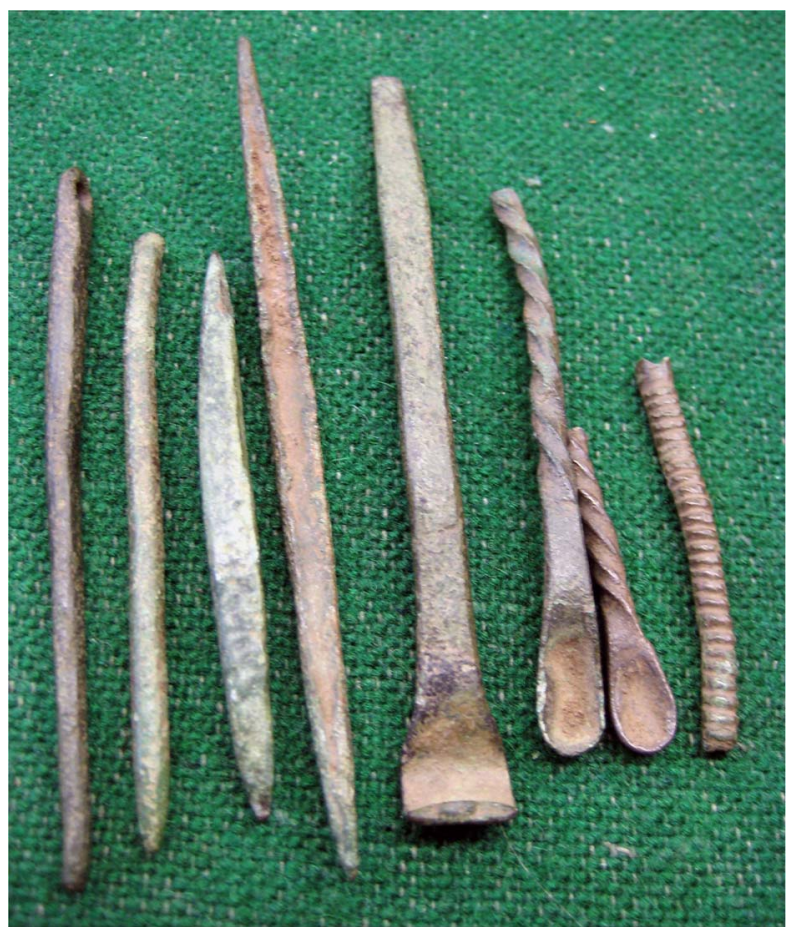

Fig 25. Some iron tools from Torksey, including awls and spoon bits. Photograph:

(C) Fitzwilliam Museum, Cambridge

contrast, notable that excavation and metal-detecting for iron at Woodstown recovered hundreds of ferrous items, many seemingly associated with ship repair. ${ }^{\text {IO3 }}$

A range of other artefacts also seem likely to derive from overwintering activities. The presence of spindle whorls, needles, punches and awls suggest textile-working, presumably including the repair of sails, tents and clothing (fig 25). Meanwhile, 289 lead gaming pieces serve as a reminder that the Army may have had leisure time on its hands (fig 26). This all suggests that the study of the impact of Viking raids in the late ninth century needs to broaden its focus beyond the purely military. Indeed, few items related to military activity have been recovered - merely two iron spearheads, an iron sword hilt and an arrowhead.

\section{THE COMPOSITION AND SIZE OF THE VIKING GREAT ARMY}

The winter camp at Torksey was evidently occupied not only by warriors, but also by merchants and craftworkers. Women and children may also have been present, as they are certainly recorded as accompanying Viking armies in contemporary continental sources and in the Chronicle entries for 893 and $895 .{ }^{\text {I04 }}$ While no oval brooches typical of female Scandinavian dress have been recovered, and the other items of jewellery and dress accessories found cannot be confidently assigned to a specific gender, the textile-working equipment from Torksey may reflect a female presence. Elsewhere, textile-working spindle

I03. Bill 20I4.

I04. Hadley and Hemer 20I I, 64-5; Whitelock I96I, 55, 57. 


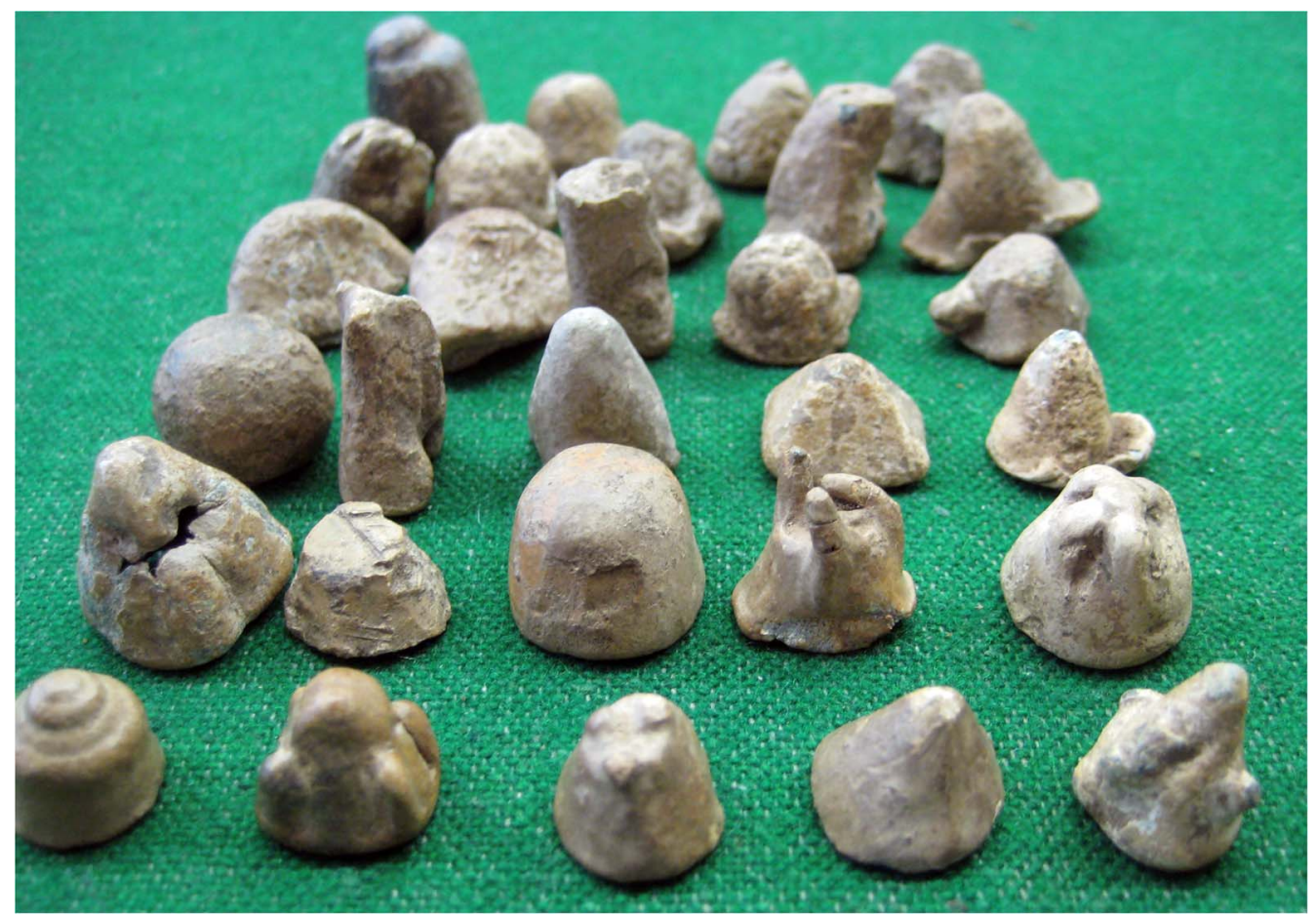

Fig 26. Examples of lead gaming pieces from Torksey. Photograph: (C) Fitzwilliam Museum, Cambridge

whorls, needles and needle cases, linen smoothers and shears, are overwhelmingly found in the graves of females. ${ }^{105}$ Moreover, there are females among the individuals buried at the Great Army's cemetery at Heath Wood (Derbyshire) and among the mass burial at Repton, including one for whom stable isotope analysis has suggested a childhood spent in midcontinental or Baltic Europe. ${ }^{\text {Io6 }}$

Documentary and archaeological evidence reveals that the Great Army was not a single unified force, but, rather, comprised multiple warbands drawn from different parts of Scandinavia. In the unusually detailed account of the Great Army's battles with the West Saxon forces in $87 \mathrm{I}$, it is apparent that it was led by at least two kings - Halfdan and Bagsecg - and a number of jarls, with the army dividing into two at various stages. Moreover, it was reinforced in this year by what the Chronicle describes as a 'great summer army'. ${ }^{\text {107 }}$ The differing burial strategies adopted subsequently at Repton and Heath Wood - inhumation and cremation, respectively - have similarly been interpreted as indications of the differing factions within the Great Army, which divided in two after the overwintering at Repton. ${ }^{108}$ Stable isotope analysis of three males buried in furnished graves at Repton reveal that they were from diverse regions within Scandinavia. ${ }^{\text {I09 }}$

I05. Graham-Campbell and Batey 1998.

I06. Budd et al 2004, 138 .

107. Whitelock I96I, 47.

I08. Richards et al 2004 .

I09. Budd et al 2004, I37-8. 


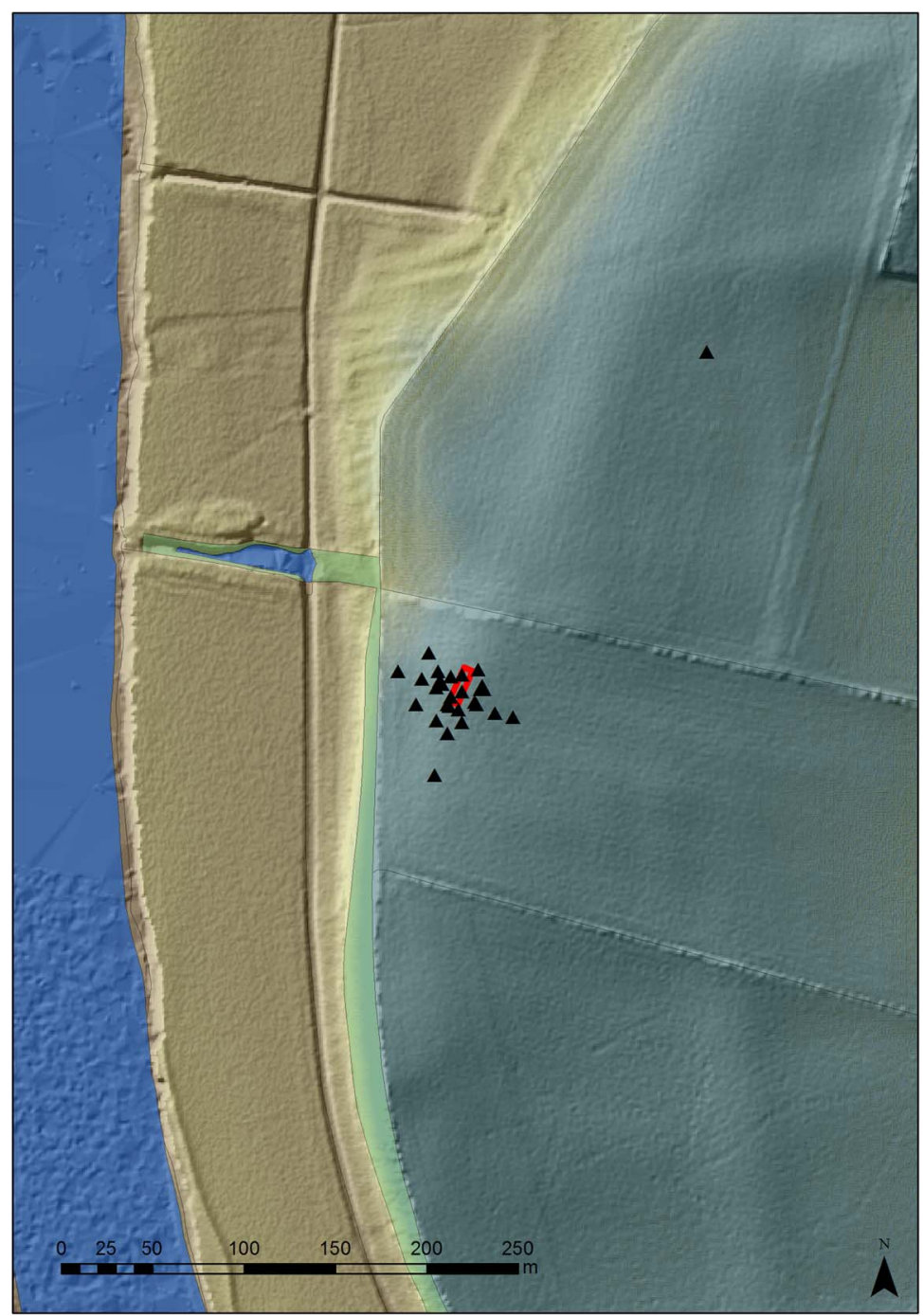

Fig 27. Plan showing the location of TORKI2 test trench (red) and find-spots of hand-collected human bone (black triangles)

In this context, it is striking that evidence for two areas of burial has been found within the winter camp at Torksey. The fieldwalking programme recovered seventy fragments of definite or possible human remains (fig 27); two samples were radiocarbon-dated to the late ninth century. ${ }^{\text {IIO }}$ Excavation revealed that modern ploughing had disturbed the site down to the underlying clay derived from the Mercia Mudstone; therefore, it was not possible to confirm the presence of graves, although further fragments of human remains were recovered. ${ }^{\text {III }}$ Nonetheless, the excavations were useful in revealing that the geology is different here,

IIO. Hadley and Richards 20I6a; the radiocarbon dates for two samples were AD 770-900/ AD 920-40 and $\mathrm{AD} 830-40 / \mathrm{AD} 870-900$ (at 95 per cent probability).

III. Richards 2013 . 


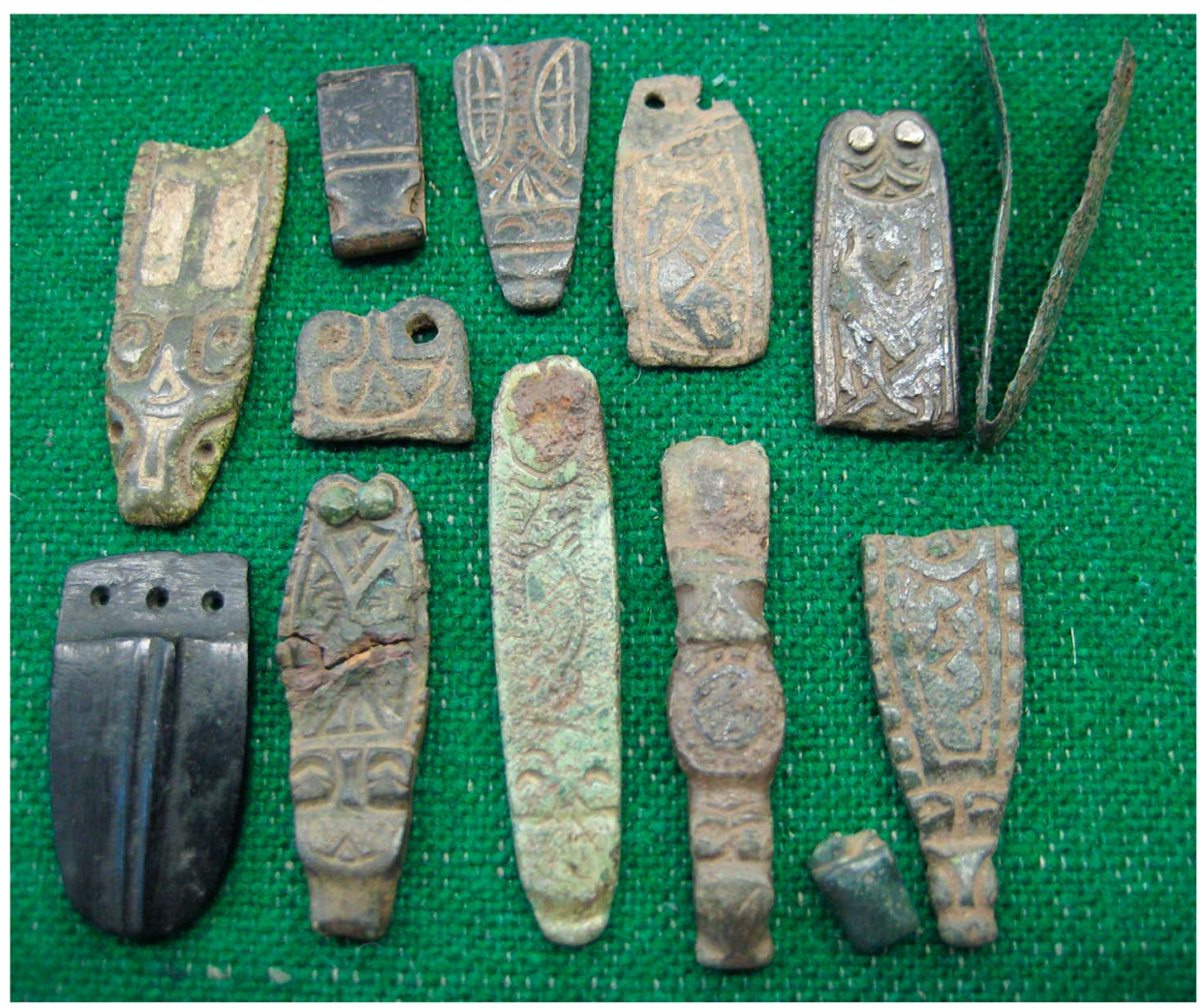

Fig 28. Examples of Anglo-Saxon strap ends from Torksey. Photograph: (C) Fitzwilliam Museum, Cambridge

with badly draining natural clay lying beneath the ploughsoil, rather than the free-draining sandy soils to the east; this may help to explain the choice of this site for burial, on the ridge overlooking the Trent, as in the case of Heath Wood. Unfortunately, the human remains were so fragmentary that a minimum number of only two adults, both probably male, could be confidently identified, aged 18-25 and 25-35 years, respectively. A fragment of occipital, consistent with the human cranium, shows evidence of two separate blows from a sharp implement, providing compelling evidence for a violent, and probably fatal, encounter. ${ }^{\text {II } 2}$ A further human cranial fragment was recovered $c 200 \mathrm{~m}$ to the north east, which may indicate a second burial area within the camp, possibly reflecting another warband within the Army.

It is possible that the presence of Anglo-Saxon slaves and hostages, and perhaps even allies acquired during their campaigns, explains some of the Anglo-Saxon dress accessories and jewellery recovered from Torksey. These were almost exclusively Anglo-Saxon in origin, and include I33 copper-alloy strap ends, the majority decorated in the late ninthcentury Anglo-Saxon Trewhiddle style (fig 28), as well as hooked tags (fig 29). However, it is also possible that Anglo-Saxon material culture was being acquired and used by Scandinavians even before permanent settlement. Indeed, a disc brooch of the flat Anglo-Saxon form decorated in the Scandinavian Borre style may suggest the presence of

II2. Craig-Atkins 2015 . 


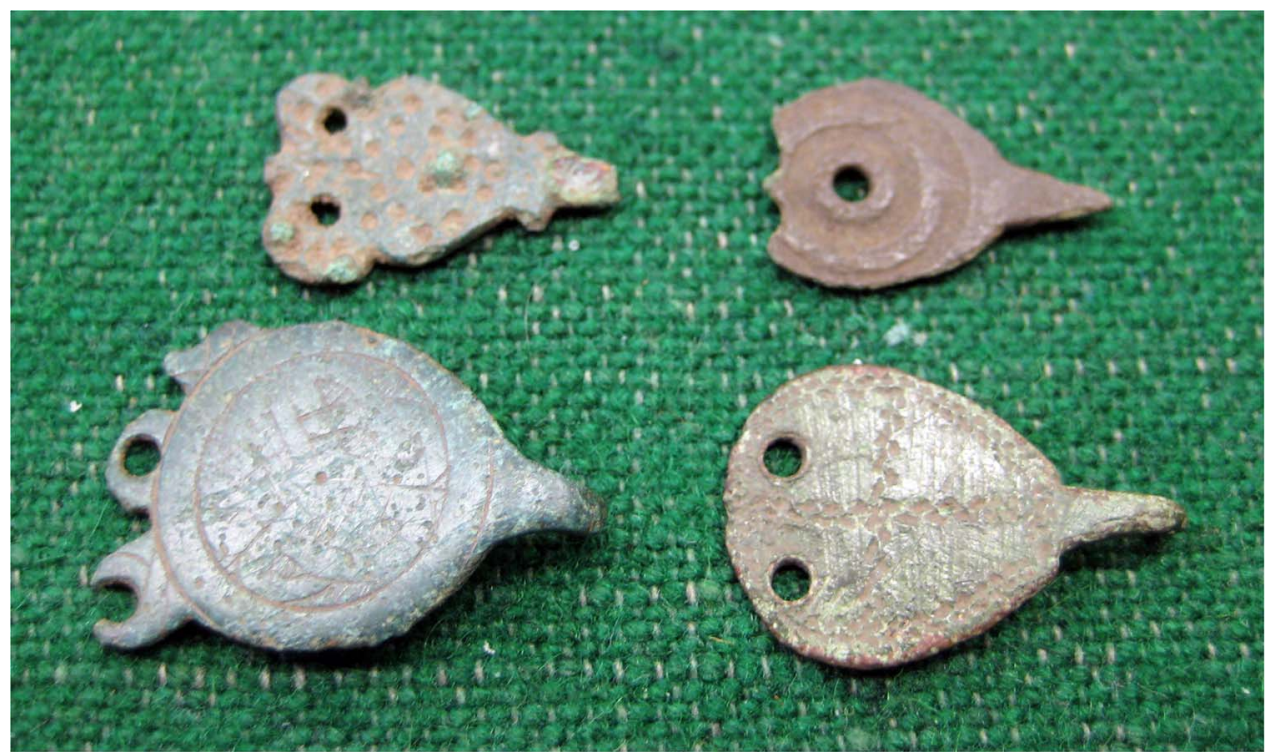

Fig 29. Examples of Anglo-Saxon hooked tags from Torksey. Photograph: (C) Fitzwilliam Museum, Cambridge

local metalworkers producing dress accessories to meet the tastes of the raiders. ${ }^{\text {II } 3}$ Furthermore, the presence of metalwork from Ireland and Frankia may reveal something of the diverse places to which members of the Great Army had travelled, and the people, cultures and economic systems they had encountered.

The evidence from Torksey also has considerable implications for our understanding of the size of the Viking Great Army. Although not all of the 55ha is likely to have been as densely occupied as a later town - and it may have comprised separate zones for the distinct groups that made up the Army, for industrial and trading activities and for living space and burial - the clear implication is that the population of the camp numbered in the thousands, not the hundreds. The Repton camp now seems rather small at 0.4 ha to have accommodated an army and its accompanying camp followers, and it appears implausibly small in the context of the camp at Torksey. The Torksey camp is also considerably larger than Woodstown at 2.9Iha and is more comparable with the winter camp at Aldwark, which is estimated to extend over $3 \mathrm{Iha}$; although smaller, this may reflect the fact that Aldwark dates to a few years later, after the Great Army had divided in two. ${ }^{\text {II } 4}$ The scale of Torksey is striking given that it has been estimated that the four major urban places in Scandinavia - Birka at $c$ 6ha; Kaupang at $c 5.4$ ha; Ribe (Denmark) at $c$ I 2 ha; and Hedeby (Germany) at $c$ 24ha - were all considerably smaller, even at their maximum extent in the tenth century. ${ }^{\text {II5 }}$

Without doubt, given the size of the camp, the Great Army and its followers, probably including women and children as well as traders and craftworkers, comprised thousands of people. We can never know exact numbers, but if a fleet comprised 50-I00 longships, and

II3. Hadley and Richards 20I6a, finds catalogue NLM-72DiC7.

II4. Russell and Hurley 20I4; Williams 20I5, 99.

II5. Skre 2008a. 
each ship had a crew of thirty to fifty warriors, then an army within the range $1,500-5,000$ is not implausible, and could easily have been accommodated on the island at Torksey. The Anglo-Saxon Chronicle references to fleets of several hundred ships may not have been exaggerations after all.

\section{WHY TORKSEY?}

The choice of Torksey was doubtless partly determined by its easily defendable position at a junction of river and road routes. However, it was not the only option facing the Great Army, as there are other suitable locations along this stretch of the Trent, including a similar 'island' $4 \mathrm{~km}$ south at Kettlethorpe.${ }^{\text {II }}$ It is difficult to assess the specific appeal of Torksey, given that we have no written record pre-dating the Chronicle entry and little archaeological evidence that is reliably earlier. David Stocker has proposed that there was an Anglo-Saxon 'beach market' associated with St Margaret's Church at Marton just to the north of the camp. However, the basis for this argument is Sawyer's suggestion that the metalwork from what is now known to be the site of the winter camp derived from a market of eighth- and ninth-century date, and the presence of multiple stone sculptures of the second quarter of the tenth century at St Margaret's. ${ }^{117}$ There is nothing to indicate significant activity prior to $872-3$, even following our fieldwalking on the site of the winter camp and in the fields to the south of the village. Only a single sherd of handmade early Anglo-Saxon pottery has been recovered during excavation in the village, while sherds of two sixth-century vessels recorded by J N L Myres are from unknown find-spots within the parish. ${ }^{\text {II } 8}$ Two sixth-century brooches have been recovered by metal detectorists east of the village. ${ }^{119}$ Excavation in the I960s of one of the pottery kilns to the south of the village - which has since been dated to the late ninth century - revealed traces of an earlier building comprising stone foundations laid in clay, but nothing else is known of the building. ${ }^{\text {I2O }}$

The early history of Torksey is obscure. It was held by Queen Edith in 1066, but we cannot discern how long it had been a royal landholding. ${ }^{\text {II }}$ There is some intriguing evidence that the parish churches of St Peter and St Mary were part of an early ecclesiastical complex, principally in the form of their juxtaposition, and the pairing of their dedications, which has been found at early monastic complexes. However, they have produced no early structural evidence and our radiocarbon dating of cist graves associated with the church of St Mary has produced only eleventh-century dates. Within and around the modern village of Torksey, three further cemeteries have been excavated that date broadly to the later Anglo-Saxon centuries (fig 30), but neither radiocarbon dating nor stratigraphic evidence dates these any earlier than the tenth century. ${ }^{\text {I22 }}$

The Great Army repeatedly spent the winter adjacent to major centres, such as Repton where there was an important Mercian ecclesiastical site and royal shrine. ${ }^{\text {I23 }}$ It has recently been argued that longphuirt in Ireland were typically located at the boundaries between kingdoms, where Viking armies can be found intervening in internecine rivalries. ${ }^{\text {I24 }}$ However,

II6. Stein 2015.

II7. Stocker 2000, I89-9I.

II 8. Pre-Construct Archaeology 1996; Myres 1951, 88-9.

I 19. PAS LIN-ODA724 and LIN-850F66.

I20. Barley 1964, I87; Brown 2012b.

I2I. Foster and Longley I924, II-I3.

I22. Hadley and Richards 20I6b; the radiocarbon dates for the cist graves are AD IO3O-I2IO and AD I025-II65 (at 95 per cent probability).

I23. McLeod 2006.

I24. Kelly 2015, 91. 


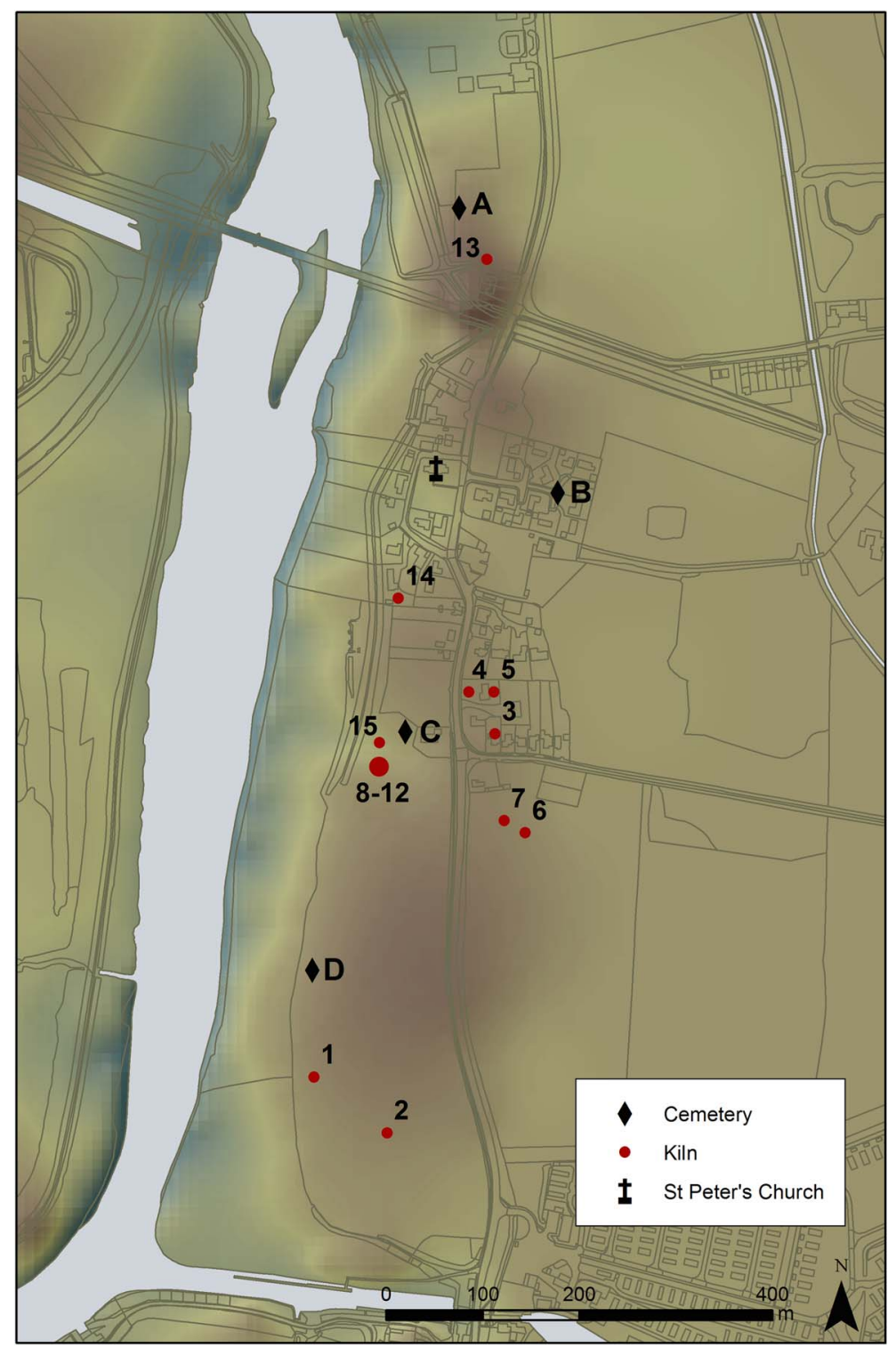

Fig 30. Map of Torksey showing the location of the Torksey ware pottery kilns (red dots) and the Anglo-Saxon cemeteries (black lozenge)

there is little to confirm whether similar factors were relevant to the choice of Torksey as a place to overwinter. Nonetheless, there are several major churches in the vicinity. Stow, just $4 \mathrm{~km}$ north east, was an episcopal possession in the eleventh century. Given the interest shown in it by the archbishops of York and the bishops of Dorchester, it has been suggested that the church was an endowment of the revived bishopric of Lindsey from the 950s. The cruciform church has a large central tower built in the mid-eleventh century under archiepiscopal 
patronage. ${ }^{125}$ The part of the winter camp that was in the parish of Brampton was held by the Bishop of Lincoln in the thirteenth century, and may have been the subject of a grant to Stow in the I050s by Earl Leofric of Mercia and his wife Godgifu, but the association with Stow cannot confidently be traced back any further. ${ }^{\text {I26 }}$ Across the Trent from Torksey is another church with early origins at South Leverton (Nottinghamshire), from where fragments of late eighth- or early ninth-century sculpture have recently been recovered. ${ }^{\text {I27 }}$ The strategic potential of the camp, in the vicinity of at least two major churches, may, therefore, partially account for the choice of Torksey as a base for the Great Army.

The Great Army would also have needed to provision itself, and the potential of accessing the food renders owed to major churches may have been another key factor in choosing where to overwinter. Food and other resources may have been offered as part of the peace settlements made when the Army overwintered, such as those recorded in Frankia in the 860 s. ${ }^{128}$ The Army was also able to exploit natural resources, as demonstrated by the recovery of fishing weights. ${ }^{\text {I29 }}$ It would have required access to a variety of raw materials, including timber and canvas for the construction of temporary winter accommodation, as well as for fuel and ship repair, and clay for the manufacture of moulds and hearths necessary for metal-casting and smithying. These resources may have been acquired by a combination of foraging, of the type Asser says occurred during the overwintering at Reading on the Thames in $870-\mathrm{I}$, and purchase, which is what some of the coinage and bullion may have facilitated. ${ }^{\mathrm{I}}{ }^{\circ}$ Indeed, one of the largest assemblages of stycas outside Northumbria, other than Torksey itself, comes from Littleborough. The date profile of the twenty-five stycas is almost identical to that of the Torksey assemblage, and may indicate contemporaneous activity. ${ }^{\text {I3I }}$ Clearly, the army must have reached some form of accommodation with the local population, albeit enforced. The winter camps, like the towns that succeeded them, must have had hinterlands that extended for several kilometres. Indeed, the association between the camp at Repton with the Viking cemetery at Heath Wood, some $4 \mathrm{~km}$ to the south east, underlines the need to consider the camps at a landscape level, not as single sites. ${ }^{132}$ No doubt the sudden arrival of a settlement the size of a small town had a major impact on the locality. ${ }^{\text {I33 }}$

\section{WHAT HAPPENED NEXT?}

The Great Army did not merely spend a few months in a locale and then move on; its leaders often attempted to maintain some level of control. Sometimes, they appointed a ruler from the local elite, as demonstrated at Repton where they replaced Burgred with Ceolwulf II, while the Anglo-Saxon successors of Edmund of East Anglia (d. 869) minted coins that, in the words of Blackburn, displayed 'all the hallmarks of a Viking coinage', suggesting they were 'puppet kings'. ${ }^{134}$ Beyond the fact that the

I25. Everson and Stocker forthcoming.

I26. Foster and Longley 1924, 47; Sawyer 1998, 246-52; contra Stein 2015, 307.

127. Stocker and Everson 2007.

I28. Nelson I99I, 95, I I2, I64; McLeod 2006, I46; Stafford I980.

I29. Blackburn 20II, 240-I, 244.

130. Keynes and Lapidge 1983, 78.

I3I. Abramson 2016.

132. Richards et al 2004.

I33. Williams 2013, 30-2.

I34. Whitelock I96I, 48; Blackburn 2005, 29; McLeod 20I4, I73-203. 
Anglo-Saxon Chronicle notes that the Great Army made peace with the Mercians at Torksey, their ensuing local interactions are unrecorded. However, Torksey is well known for its wheel-thrown pottery industry, which developed in the wake of the overwintering. Torksey ware has not been recovered from excavated contexts reliably pre-dating the end of the ninth century in York or Lincoln, and none was recovered from the winter camp during our fieldwalking. Torksey was at the forefront of a revolution in ceramic production, which witnessed the reintroduction of the fast potter's wheel for the first time since the Roman period, and the use of updraft kilns producing high-fired sand-tempered vessels on a near industrial scale. The involvement of Carolingian potters has long been suspected, given that the fast wheel had remained in use on the continent. ${ }^{\mathrm{I} 35}$

Torksey ware has been found widely in eastern and northern England. It has previously been suggested that 'Torksey-type' ware was also produced in York, following the presumed foundation of a 'daughter industry' of Torksey, but fabric analysis conducted as part of the present project has revealed that this pottery was, in fact, produced in Torksey and transported north. ${ }^{136}$ The arrival of Carolingian potters was part of the legacy of the overwintering of the Great Army, and our project has revealed the pottery industry at Torksey was of regional significance, and must have been crucial to the emergence of a thriving urban settlement with 213 burgesses by $1066 .{ }^{137}$ By the turn of the eleventh century Torksey possessed a mint, and by the twelfth century a court. ${ }^{138}$ It has accordingly been suggested that Torksey was one of the 'seven boroughs' referred to within the Anglo-Saxon Chronicle entry for IOI5, thought to have included the 'five boroughs' of Derby, Lincoln, Nottingham, Stamford and Leicester named in the Chronicle entry for 942, along with two others. ${ }^{139}$ There were at least three parish churches and two monasteries in Torksey by the twelfth century, serving as another marker of its urban growth in the centuries following the Viking overwintering. ${ }^{140}$

\section{CONCLUSIONS}

In summary, our research at Torksey has revealed not only the location of the Viking winter camp, but something of its character as well. The sheer quantity and value of the metalwork assemblage forces a radical reappraisal of the scale of wealth amassed by the Viking Great Army. Plunder was being processed on a massive scale. There was intensive trade and exchange in goods and probably in slaves. The evidence from Torksey suggests a hybrid economy with monetary as well as bullion transactions and the minting of coins, reflecting something of the complexity of the multiple economic systems that co-existed during the Viking Age. ${ }^{\text {III }}$

Torksey also forces us to reassess our interpretation of the size of the winter camps, and of the Great Army that occupied them. Hitherto, our picture of Viking encampments has largely been derived from the excavations at Repton, but it is now clear that even if the $\mathrm{D}$-shaped enclosure was, indeed, the work of the Great Army it can only reflect a small part

I35. Perry 2016.

I36. Ibid.

I37. Foster and Longley I924, II.

I38. Barley 1964, I67; Dolley and Strudwick 1956.

139. Whitelock I96I, 7I, 94.

I40. Barley I964.

I4I. Williams 20I5, I04-8. 
of the Viking encampment. It is apparent that much antiquarian, and even some modern, speculation about the potential locations of Viking winter camps is misguided; researchers have been seeking sites that are far too small and have been lured into an unnecessary search for D-shaped enclosures. ${ }^{142}$ The unusual concentration of people in such camps has been revealed by our work at Torksey, and they may have given many of the members of the Viking armies their first taste for urban living. ${ }^{43}$ Other urban features included a range of industries, comprising the processing of precious metals and other metal-working, smithying and textile-working. Although pottery manufacture was not undertaken on the camp, the development of the Torksey ware industry followed soon after the Army departed, and was a direct result of its overwintering, following the arrival of Carolingian potters who introduced the technology. ${ }^{\mathrm{I} 4}$

Our research at Torksey has demonstrated the huge importance of the winter camp and its legacy as well as its role for our understanding of the Viking Great Army and the development of urban life in ninth-century England. Indeed, there is already more evidence for ninth-century activity from Torksey than from the 'five boroughs' combined. Future fieldwork may well reveal more about the nature of camp life, including temporary living structures, industrial hearths and faunal assemblages, and the processes by which the town of Torksey developed.

\section{ACKNOWLEDGEMENTS}

The Anglo-Saxon and Viking Torksey project is a collaboration between the Universities of Sheffield and York, with the additional participation of staff of the Portable Antiquities Scheme and York Museums Trust. Dawn Hadley and Julian Richards would like to thank Gareth Williams (British Museum), Helen Goodchild, Andrew Marriott, Virginia Pichler (University of York), Lily Carhart, Elizabeth Craig-Atkins, Samantha Stein, Diana Mahoney-Swales, Gareth Perry (University of Sheffield), Andrew Woods (York Museums Trust), Adam Daubney, Rachel Atherton (PAS), Hannah Brown (freelance geophysicist) and Jane Young (freelance pottery specialist), as well as all the metal-detector users who have worked with us, notably Dave and Pete Stanley and Neil Parker.

We are also grateful to the landowners, Rodger Brownlow, Derrick Small and Dick Denby, for allowing us access and to Ben Robinson of Historic England for the Section 42 licence to undertake geophysical survey in the Castle Field, Scheduled Ancient Monument I00499I.

Funding was provided by the British Academy and the Society of Antiquaries of London, with additional support from the Quaternary Research Association, the Medieval Settlement Research Group, the Robert Kiln Trust and the Universities of Sheffield and York.

A number of colleagues kindly commented on earlier drafts of this paper, including James Graham-Campbell, Caroline Jackson and John Moreland, and we would also like to thank the fournal's two anonymous referees. Our greatest debt, however, is to the late Mark Blackburn, who first brought the site to our attention and encouraged this archaeological investigation.

I42. Edgeworth 2008.

I43. Williams 2013.

I44. Perry 2016. 


\section{BIBLIOGRAPHY}

Abramson, T 2016. " Where there's muck there's brass!": coinage in the Northumbrian landscape and economy, c 575-c 867', unpublished $\mathrm{PhD}$ thesis, University of York

Archibald, M 20II. 'Testing', in J GrahamCampbell, The Cuerdale Hoard and Related Viking Age Silver and Gold, from Britain and Ireland in the British Museum, 5I-64, British Mus Res Publ I85, London

Aspinall, A 1984. 'Repton magnetometer and earth resistance survey', unpublished survey report, Bradford University

Barley, M W 1964. 'The medieval borough of Torksey: excavations I960-2', Antiq F, 44, I65-87

Barley, M W I98I. 'The medieval borough of Torksey: excavations I963-8', Antiq F, 6r, 264-9I

Biddle, $M$ and Kjølbye-Biddle, B I992. 'Repton and the Vikings', Antiquity, 66, 36-5I

Biddle, $M$ and Kjølbye-Biddle, B 200I. 'Repton and the "great heathen army", 873-4', in Graham-Campbell et al 200I, 45-96

Bill, J 20I4. 'Nails', in Russell and Hurley 20I4, I4I-55

Blackburn, M 200I. 'Expansion and control: aspects of Anglo-Scandinavian minting south of the Humber', in Graham-Campbell et al 200I, I25-55

Blackburn, M 2002. 'Finds from the AngloScandinavian site of Torksey, Lincolnshire', Moneta Mediaevalis: Studia numizmatyczne $\breve{\imath}$ historyczne ofiarowane Profesorowi Stanistawowi Suchodolskiemu w 64. roxcnice urodzin, 89-IOI, 526-7

Blackburn, M 2005. 'Presidential address 2004. Currency under the Vikings. Part I: Guthrum and the earliest Danelaw coinages', Brit Numis f, 75, I8-43

Blackburn, M 2007. 'Gold in England during the "Age of Silver" (eighth-eleventh centuries)', in Graham-Campbell and Williams $2007,55-98$

Blackburn, $M$ 2008. 'The coins finds', in Skre 2008b, 29-74

Blackburn, M 20II. 'The Viking winter camp at Torksey, 872-3', in Viking Coinage and Currency in the British Isles, 22 I-64, Brit Numis Soc Spec Publ 7, London

Brooks, N I979. 'England in the ninth century: the crucible of defeat', Trans Roy Hist Soc, 5th ser, 29, I-20
Brooks, N and Graham-Campbell, J 2000.

'Reflections on the Viking Age silver hoard from Croydon, Surrey', in N Brooks, Communities and Warfare 700-I400, 69-9I, Hambledon, London

Brown, H 20I2a. 'Magnetometer survey of land north of Torksey, Lincolnshire', unpublished report, University of York (doi: 10.5284/1038043)

Brown, H 20I2b. 'Geophysical survey at Torksey, Lincolnshire: magnetometer survey of land south of Torksey Castle', unpublished report, University of York (doi: I0.5284/I03804I)

Budd, P, Millard, A, Chenery, C, Lucy, S and Roberts, C 2004. 'Investigating population movement by stable isotope analysis: a report from Britain', Antiquity, 78, I27-4I

Cameron, $\mathrm{K}$ and Insley, J 2010. The Place Names of Lincolnshire. Part 7: Lawress Wapentake, English Place-Name Society, Nottingham

Carhart, L 2015. 'An iron hoard from Torksey, Lincolnshire: identification and analysis', unpublished MA dissertation, University of Sheffield (doi: I0.5284/1038398)

Clarke, H B and Johnson, R (eds) 2015. The Vikings in Ireland and Beyond, Four Courts Press, Dublin

Coates, R 2008. 'Reflections on some Lincolnshire major place names. Part I: Algakirk to Melton Ross', $\mathcal{f}$ Engl Place-Name Soc, 40, 35-95

Cole, A I992. 'Distribution and use of the Old English place-name mere-tūn', $\mathcal{F}$ Engl Place-Name Soc, 24, 30-4I

Cole, R E G 1906. 'The royal borough of Torksey, its churches, monasteries and castle', Ass Architect Soc Rep Pap, 29, $45 \mathrm{I}-530$

Craig-Atkins, E 2015. 'The human remains from the winter camp', unpublished report, University of Sheffield (doi: I0.5284/I038397)

Dolley, R H M and Strudwick, J S I956. 'A note on the mint of Torksey and on some early finds of English coins from Nottinghamshire', Numis Chron, 16, 293-302

Edgeworth, M 2008. 'The Tempsford project: an interim report', South Midlands Archaeol, $38,8-16$

Edwards, J F and Hindle, B P I991. 'The transportation system of medieval England and Wales', $\mathcal{f}$ Hist Geogr, 17 (2), I23-34 
Everson, P and Stocker, D forthcoming.

'Archaeology and episcopal reform: greater churches in York diocese in the IIth century', in D M Hadley and C C Dyer (eds), The Archaeology of the Eleventh Century: continuities and transformations, Routledge, London

Field, N 1990. 'Castle Farm, Torksey, exploratory excavations', unpublished report, Lindsey Archaeological Services, Lincoln (doi: I0.5284/IOI 2874)

Foster, C W and Longley, T 1924. The Lincolnshire Domesday and the Lindsey Survey, Publications of the Lincoln Record Society 19, Lincoln

Gould, I C 1903. 'Ancient earthworks', in H A Doubleday and W Page (eds), Victoria History of the County of Essex. Vol I, 286-7, Archibald Constable, London

Graham-Campbell, J 200I. 'The dual economy of the Danelaw', Brit Numis f, 71, $49-59$

Graham-Campbell, J 2004. 'The archaeology of the "Great Army" (865-79)', in E Roesdahl and J P Schjødt (eds), Beretning fra treogtyvende tvcrfaglige vikingesymposium, 30-46, Aarhus Universitet, Højbjerg

Graham-Campbell, J and Batey, C i998. Vikings in Scotland: an archaeological survey, Edinburgh University Press, Edinburgh

Graham-Campbell, J, Hall, R, Jesch, J and Parsons, D (eds) 200I. Vikings and the Danelaw: Proceedings of the Thirteenth Viking Congress, Oxbow, Oxford

Graham-Campbell, J and Williams, G (eds) 2007. Silver Economy in the Viking Age, Left Coast Press, Walnut Creek, California

Guilbert, G 2004. 'Borough Hill, Walton-uponTrent - if not a hillfort, then what?', Derbyshire Archaeol f, 124, 242-57

Hadley, D M 2006. The Vikings in England: settlement, society and culture, Manchester University Press, Manchester

Hadley, D M and Hemer, K 20I I. 'Microcosms of migration: children and early medieval population movement', Childhood in the Past, 4, 63-78

Hadley, D M and Richards, J D (eds) 2000. Cultures in Contact: Scandinavian settlement in England in the ninth and tenth centuries, Brepols, Turnhout

Hadley, D M and Richards, J D 2016a. Archaeological Evaluation of the Anglo-Saxon and Viking Site at Torksey, Lincolnshire, Archaeology Data Service, York (doi: $10.5284 /$ IOI 8222 )
Hadley, D M and Richards, J D 20I6b. 'The Viking winter camp and AngloScandinavian town at Torksey, Lincolnshire: the landscape context', in V E Turner, O A Owen and D J Waugh (eds), Shetland and the Viking World: papers from the seventeenth Viking Congress, Lerwick, I27-39, Shetland Amenities Trust, Lerwick

Haldenby, D and Richards, J D 2016. 'The Viking Great Army and its legacy: plotting settlement shift using metal-detected finds', Internet Archaeol, 42 (doi: Io.I I I4I/ia.42.I)

Hall, R 1994. Viking Age York, Batsford, London

Holm, P I986. 'The slave trade of Dublin, ninth to twelfth centuries', Peritia, 5, 317-45

Hurley, M 20I4. 'Discussion and conclusions', in Russell and Hurley 2014, 347-57

Kelly, E P 20I5. 'The longphort in Viking Age Ireland', in Clarke and Johnson 2015, 55-92

Kershaw, J 2013. Viking Identities: Scandinavian jewellery in England, Oxford University Press, Oxford

Kershaw, P 2000. 'The Alfred-Guthrum treaty: scripting accommodation and interaction in Viking Age England', in Hadley and Richards 2000, 43-64

Keynes, S and Lapidge, M 1983. Alfred the Great: Asser's Life of King Alfred and other contemporary sources, Penguin, Harmondsworth

Kilger, C 2008. 'Wholeness and holiness: counting, weighing and valuing silver in the early Viking period', in Skre 2008b, 253-326

Mahoney-Swales, D and Perry, G 2014. 'Report on an evaluation trench excavated near Torksey, Lincolnshire, 29 July2 August 2013', unpublished report, University of Sheffield (doi: I0.5284/ I038396)

McLeod, S 2006. 'Feeding the micel here in England, c 865-878', $\mathcal{F}$ Australian Early Medieval Soc, 2, I4I-56

McLeod, S 2014. The Beginning of Scandinavian Settlement in England, Brepols, Turnhout

Myres, J N L i951. 'The Anglo-Saxon pottery of Lincolnshire', Archaeol F, 108, 65-99

Naismith, R 2005. 'Islamic coins from early medieval England', Numis Chron, I65, 193-222

Nelson, J 1991. The Annals of St-Bertin, Manchester University Press, Manchester

Ó Floinn, R 20I4. 'Cast and gilt copper alloy', in Russell and Hurley 20I4, I72-92 
Oswald, A 1937. Roman Pottery Kilns at Little London, Lincs, Rock House, Wellow

Palmer-Brown, C i995. 'Castle Farm, Torksey, an archaeological excavation report CFT94', unpublished report, Pre-Construct Archaeology, Lincoln (doi: I0.5284/IOI2796)

Pedersen, U 2008. 'Weights and balances', in Skre 2008b, II $9-95$

Pelteret, D i980. 'Slave raiding and slave trading in early England', Anglo-Saxon Engl, 9, 99-II4

Perry, G 20I6. 'Pottery production in AngloScandinavian Torksey (Lincolnshire): reconstructing and contextualising the chaîne opératoire', Medieval Archaeol, 60 (I), 72-II4

Pestell, T 2013. 'Imports or immigrants? Reassessing Scandinavian metalwork in late Anglo-Saxon East Anglia', in D Bates and R Liddiard (eds), East Anglia and its North Sea World in the Middle Ages, 230-55, Boydell, Woodbridge

Pettersson, A (ed) 2009. The Spillings Hoard: Gotland's role in Viking Age world trade, Gotlands Museum, Visby

Pirie, E J E 2000. Thrymsas, Sceattas and Stycas of Northumbria: an inventory of finds recorded, to 1997, Northumbrian Numis Stud 2, Llanfyllin

Pre-Construct Archaeology 1996.

'Archaeological field evaluation report "Verity", Church Lane, Torksey', unpublished report, Pre-Construct Archaeology, Lincoln

(doi: I0.5284/I0I5219)

Purcell, E 2015. 'The first generation in Ireland, 795-8I2: Viking raids and Viking bases?', in Clarke and Johnson 2015, 4I-54

Raffield, B 2013. "'A river of knives and swords": ritually deposited weapons in English watercourses and wetlands during the Viking Age', European $\mathcal{F}$ Archaeol, $\mathbf{7}$ (4), 634-55

Richards, J D 20I3. 'Torksey test trench 20I2: report on a trial trench excavated near Torksey, Lincolnshire, I3-I6 Dec 2012', unpublished report, University of York (doi: $10.5284 / 1038042$ )

Richards, J D, Austin, T, Bateman, J, Bell, S, Birchall, K, Brothwell, D, Campbell, E, Carrott, J, Dobney, K, Garner-Lahire, J and Gaunt, G 1999. 'Cottam: an Anglian and Anglo-Scandinavian settlement on the Yorkshire Wolds', Archaeol F, I56, I-I I I

Richards, J D, Beswick, P, Bond, J, Jecock, M, McKinley, J, Rowland, S and Worley, F 2004. 'Excavations at the Viking barrow cemetery at Heath Wood, Ingleby, Derbyshire', Antiq f, 84, 23-II6

Richards, J D, Naylor, J and Holas-Clark, C 2009. 'Anglo-Saxon landscape and economy: using portable antiquities to study Anglo-Saxon and Viking Age England', Internet Archaeol, 25 (doi: IO.I I I4I/ia.25.2)

Riley, D N, Buckland, P C, Wade, J, Dearne, M, Hartley, B, Hartley, K, Kinsley, G and O'Connor, T I995. 'Aerial reconnaissance and excavation at Littleborough-on-Trent', Britannia, 26, 253-84

Rowe, E 2008. 'Land to the north of the railway, Torksey, Lincolnshire: archaeological evaluation report', unpublished report, PreConstruct Archaeology, Lincoln, <docs. west-lindsey.gov.uk> (accessed 5 Sept 20I6)

Rowlandson, I M 2005. 'Main Street, Torksey, Lincs: archaeological watching brief', unpublished report, Lindsey Archaeological Services Report No. 86I (doi: I0.5284/IOI5309)

Russell, I R and Hurley, M (eds) 2014. Woodstown: a Viking Age settlement in Co. Waterford, Four Courts Press, Dublin

Sawyer, P H 1962. The Age of the Vikings, Edward Arnold, London

Sawyer, P H 1998. Anglo-Saxon Lincolnshire, History of Lincolnshire 3, Society for Lincolnshire History and Archaeology, Lincoln

Sheehan, J 2008. 'The longphort in Viking Age Ireland', Acta Archaeologica, 79, 282-95

Sheehan, J 20I4. 'Silver', in Russell and Hurley 2014, I94-222

Skre, D 2008a. 'The development of urbanism in Scandinavia', in S Brink and N Price (eds), The Viking World, 83-93, Routledge, London

Skre, D 2008b. Means of Exchange: dealing with silver in the Viking Age, Kaupang Excavation Project Publ Ser 2, Oslo

Stafford, P I980. 'The "farm of one night" and the organisation of King Edward's estates in Domesday', Econ Hist Rev, 33 (4), $49 \mathrm{I}-502$

Stein, S 20II. 'Geoarchaeological report from Torksey, Lincolnshire, October-November 20II', unpublished report, University of Sheffield (doi: 10.5284/1038394)

Stein, S 20I2. 'Geoarchaeological report from Torksey, Lincolnshire, July and November 2012', unpublished report, University of Sheffield (doi: I0.5284/I038395)

Stein, S 2013. 'The geoarchaeology of Viking overwintering camps in England: preliminary results of a radiocarbon-dated 
palynological sequence at Brampton in Torksey, Lincolnshire', Quaternary Newsletter, 13I, 5I-4

Stein, S 2015. 'Understanding Torksey and the Viking winter camp of 872-3: a geoarchaeological and landscape approach to Viking overwintering camps', unpublished $\mathrm{PhD}$ thesis, University of Sheffield

Stocker, D 2000. 'Monuments and merchants: irregularities in the distribution of stone sculpture in Lincolnshire and Yorkshire in the tenth century', in Hadley and Richards 2000, I79-2I2

Stocker, D and Everson, P 2007. 'Two newly discovered fragments of pre-Viking sculpture: evidence for a hitherto unsuspected early church site at South Leverton, Nottinghamshire', Trans Thoroton Soc Nottinghamshire, III, 33-49

Thomas, G 2008. 'The symbolic lives of late Anglo-Saxon settlements: a cellared structure and iron hoard from Bishopstone, East Sussex', Archaeol F, I65, 334-98

Treasure Annual Report 2004. Department for Culture, Media and Sport, London

Ulmschneider, K 2000. 'Settlement, economy and the "productive site": Middle AngloSaxon Lincolnshire AD 650-780', Medieval Archaeol, 44, 53-79

Wessex Archaeology 1997. 'Blyborough, Lincs, to Cottam, Notts, pipeline: report on the archaeology', 2 vols, unpublished reports, Wessex Archaeology (doi: 10.5284/IOI547I and doi: I0.5284/IOI464I)
Whitelock, D (ed) I96r. The Anglo-Saxon Chronicle, Eyre \& Spottiswoode, London

Whitwell, J B I992. Roman Lincolnshire, Society for Lincolnshire History and Archaeology, Lincoln

Williams, G 2007. 'Kingship, Christianity and coinage: monetary and political perspectives on silver economy in the Viking Age', in Graham-Campbell and Williams 2007, I77-2I4

Williams, G 20I I. 'Silver economies, monetisation and society: an overview', in J Graham-Campbell, S M Sindbaek and G Williams (eds), Silver Economies, Monetisation and Society in Scandinavia, AD 800-IIOO, 337-72, Aarhus University Press, Aarhus

Williams, G 2013. 'Towns and identities in Viking England', in D M Hadley and L Ten Harkel (eds), Everyday Life in Viking Age Towns: social approaches to towns in England and Ireland, c 800-IIOO, 27-49, Oxbow, Oxford

Williams, G 20I5. 'Viking camps and the means of exchange in Britain and Ireland in the ninth century', in Clarke and Johnson 2015, 93-II6

Williams, $M$ and Field, N 2002. 'Main St, Torksey, Lincs. New medical centre and housing development: archaeological evaluation', unpublished report, Lindsey Archaeological Services Rep No. 557 (doi: I0.5284/IOI4664)

Young, T 20I4. 'Ceramics: crucibles and cupels', in Russell and Hurley 20I4, 267-82 